\title{
Plant growth-promoting rhizobacteria and root system functioning
}

\section{Jordan Vacheron 1,2,3, Guilhem Desbrosses ${ }^{4}$, Marie-Lara Bouffaud 1,2,3,5, Bruno Touraine ${ }^{4}$, Yvan Moënne-Loccoz 1,2,3 , Daniel Muller ${ }^{1,2,3}$, Laurent Legendre ${ }^{1,2,3}$, Florence Wisniewski-Dyé ${ }^{1,2,3}$ and Claire Prigent-Combaret ${ }^{1,2,3 *}$}

1 Université de Lyon, Lyon, France

2 Université Claude Bernard Lyon 1, Villeurbanne, France

${ }^{3}$ Centre National de la Recherche Scientifique, UMR 5557, Ecologie Microbienne, Université Lyon 1, Villeurbanne, France

${ }^{4}$ Laboratoire des Symbioses Tropicales et Méditerranéennes, UMR 113, Université Montpellier 2/Institut de Recherche Pour le Développement/Centre de Coopération Internationale en Recherche Agronomique pour le Développement/SupAgro/Institut National de la Recherche Agronomique, Montpellier, France

${ }_{5}^{5}$ Institut National de la Recherche Agronomique, UMR 1347, Agroécologie, Interactions Plantes-Microorganismes, Dijon, France

\section{Edited by:}

Boris Rewald, University of Natural Resources and Life Sciences, Austria

Reviewed by:

Francesco De Bello, Institute of Botany, Czech Academy of Sciences, Czech Republic

Faina Kamilova, Koppert Biological

System, Netherlands

*Correspondence:

Claire Prigent-Combaret, Centre National de la Recherche Scientifique, UMR 5557, Ecologie Microbienne, Université Lyon 1, 43 Boulevard du 11 Novembre 1918, 69622 Villeurbanne Cedex, France

e-mail: claire.prigent-combaret@ univ-lyon 1.fr
The rhizosphere supports the development and activity of a huge and diversified microbial community, including microorganisms capable to promote plant growth. Among the latter, plant growth-promoting rhizobacteria (PGPR) colonize roots of monocots and dicots, and enhance plant growth by direct and indirect mechanisms. Modification of root system architecture by PGPR implicates the production of phytohormones and other signals that lead, mostly, to enhanced lateral root branching and development of root hairs. PGPR also modify root functioning, improve plant nutrition and influence the physiology of the whole plant. Recent results provided first clues as to how PGPR signals could trigger these plant responses. Whether local and/or systemic, the plant molecular pathways involved remain often unknown. From an ecological point of view, it emerged that PGPR form coherent functional groups, whose rhizosphere ecology is influenced by a myriad of abiotic and biotic factors in natural and agricultural soils, and these factors can in turn modulate PGPR effects on roots. In this paper, we address novel knowledge and gaps on PGPR modes of action and signals, and highlight recent progress on the links between plant morphological and physiological effects induced by PGPR. We also show the importance of taking into account the size, diversity, and gene expression patterns of PGPR assemblages in the rhizosphere to better understand their impact on plant growth and functioning. Integrating mechanistic and ecological knowledge on PGPR populations in soil will be a prerequisite to develop novel management strategies for sustainable agriculture.

Keywords: plant-PGPR cooperation, rhizo-microbiome, rhizosphere, phytohormone, plant nutrition, ISR, functional group

\section{INTRODUCTION}

Photosynthetic terrestrial plants play key roles as ecosystem engineers (Wright and Jones, 2006; Hartmann et al., 2009). They contribute, for instance, to the establishment of specific microbial ecological niches in plant-based systems. This is particularly the case in the rhizosphere, i.e., the soil in contact with plant roots. Besides its role in plant anchorage in soil, absorption of water and ions, nutrient storage, and plant vegetative growth, the root system is in close contact with a wide range of soil microbial populations (Berg and Smalla, 2009).

Despite their interactions with the biotic environment, the root system and its rhizosphere have received much less attention by plant physiologists than the rest of the plant. Plant roots exude a huge diversity of organic nutrients (organic acids, phytosiderophores, sugars, vitamins, amino acids, nucleosides, mucilage) and signals that attract microbial populations, especially those able to metabolize plant-exuded compounds and proliferate in this microbial habitat (Bais et al., 2006; Pothier et al., 2007; Badri et al., 2009; Shukla et al., 2011; Drogue et al., 2013). Root exudates being the largest source of carbon supply within soil, the rhizosphere compartment houses a rich microbial community, comprising up to $10^{10}$ bacteria per gram of soil (Gans et al., 2005; Roesch et al., 2007) and encompassing a large diversity of taxa (Kyselková et al., 2009; Gomes et al., 2010). The corresponding microbial community associated to plant roots can be referred to as the rhizo-microbiome (Chaparro et al., 2013). Its composition is distinct from that of the microbial community of the surrounding soil, a direct consequence of bacterial competition for nutrients liberated in the vicinity of plant roots (Raynaud et al., 2008; Bulgarelli et al., 2013; Chaparro et al., 2013). Since root exudate composition changes along the root system, according to stages of plant development and to plant genotypes, the rhizomicrobiome composition differs accordingly (Berg and Smalla, 2009; Aira et al., 2010; Bouffaud et al., 2012; Bulgarelli et al., 2013; Chaparro et al., 2013). Plant-driven selection of bacteria is an important issue recently discussed in several reviews (Hartmann et al., 2009; Doornbos et al., 2012; Drogue et al., 2012; Bulgarelli et al., 2013). 
Within the rhizo-microbiome, some microorganisms can promote plant growth and provide better plant health through several indirect or direct mechanisms (Couillerot et al., 2009; Richardson et al., 2009). Beneficial plant-microbe interactions are symbiotic interactions in which costs and benefits are shared by the plants and the microorganisms (Odum and Barrett, 2005; Bulgarelli et al., 2013) and can be categorized into two main types of interactions (Drogue etal., 2012). First, mutualistic interactions correspond to intimate and mostly obligate interactions between microbes and a restricted range of compatible host plants. They generally lead to the formation of a structure specifically dedicated to the interaction (e.g., nodules during the symbiosis between nodulating rhizobia and Fabaceae, arbuscules in the endomycorrhizal symbiosis; Parniske, 2008; Masson-Boivin et al., 2009). Second, cooperations (also called associative symbioses) correspond to less obligate and specific interactions (Barea et al., 2005; Drogue et al., 2012). They involve soil bacteria able to colonize the surface of the root system (and sometimes root inner tissues) and to stimulate the growth and health of the plant, and are referred to as plant growth-promoting rhizobacteria (PGPR; Barea et al., 2005). Colonization of plant host roots by PGPR is heterogeneous along the root system; their competitiveness regarding this process is a sine qua non for plant growth promotion (discussed in Benizri etal., 2001; Compant etal., 2010; Dutta and Podile, 2010; Drogue et al., 2012). In comparison to mutualistic symbionts, PGPR are thought to interact with a large range of host plant species and to encompass a huge taxonomic diversity, especially within the Firmicutes and Proteobacteria phyla (Lugtenberg and Kamilova, 2009; Drogue et al., 2012). PGPR can enhance plant nutrition via associative nitrogen fixation, phosphate solubilization, or phytosiderophore production (Richardson etal., 2009). They can improve root development and growth through the production of phytohormones or enzymatic activities, as well as favor the establishment of rhizobial or mycorrhizal symbioses. Others can protect the plant through inhibition of phytoparasites, based on antagonism or competition mechanisms, and/or by eliciting plant defenses such as induced systemic resistance (ISR; Couillerot et al., 2009; Lugtenberg and Kamilova, 2009). Some PGPR can also help plants withstand abiotic stresses including contamination by heavy metals or other pollutants; certain are even able to increase the capacity of plants to sequester heavy metals (Jing et al., 2007; Saharan and Nehra, 2011; Tak et al., 2013). Therefore, utilizing PGPR is a new and promising approach for improving the success of phytoremediation of contaminated soils (for recent reviews see Zhuang et al., 2007; Shukla et al., 2011; Tak et al., 2013).

Understanding and quantifying the impact of PGPR on roots and the whole plant remain challenging. One strategy is to inoculate roots with a PGPR in vitro and monitor the resulting effects on plant. This showed that many PGPR may reduce the growth rate of the primary root (Dobbelaere et al., 1999), increase the number and/or length of lateral roots (Combes-Meynet et al., 2011; Chamam et al., 2013), and stimulate root hair elongation in vitro (Dobbelaere et al., 1999; Contesto et al., 2008). Consequently, the uptake of minerals and water, and thus the growth of the whole plant, can be increased. Some of these effects, including increased root and shoot biomass, are also documented for
PGPR-inoculated plants growing in soil (El Zemrany et al., 2006; Minorsky, 2008; Veresoglou and Menexes, 2010; Walker et al., 2012).

The focus of this paper is to review the main modes of action of PGPR strains, the functioning of PGPR populations, and their ecology in the rhizosphere. Description of plant-beneficial properties of PGPR has been the focus of several reviews (e.g., Vessey, 2003; Richardson et al., 2009; Bashan and de-Bashan, 2010), but without integrating actual PGPR gene expression on roots, the interactions between different PGPR populations in the rhizosphere, or the resulting plant-beneficial effects. This paper is organized into four sections. In the first section, we present the molecular mechanisms through which PGPR may affect the architecture of the root system and interfere with the plant hormonal pathways, and review our current understanding of their impact on the structural properties of the roots. In the second section, recent findings related to the impact of PGPR on the physiology of the whole plant are presented, with a focus on plant nutrient acquisition, plant transcriptome and plant metabolome. The third section shows how expression of plant-beneficial properties can be affected within the rhizosphere by molecules emitted by other microbial populations or by the plant. As PGPR strains are not acting individually in the rhizosphere, the ecology of PGPR populations and notably the complexity of the interactions taking place between PGPR populations is discussed in the fourth section. Finally, we conclude on the importance of integrating molecular investigations on the modes of action and ecology of PGPR strains with high-throughput analyses on the abundance, taxonomic/functional diversity and activity of rhizosphere microbial communities, and with the monitoring of plant molecular responses.

\section{IMPACT OF PGPR ON ROOT SYSTEM ARCHITECTURE AND ROOT STRUCTURE}

Most terrestrial plants develop their root system to explore soil and find nutrients to sustain growth. Root is a complex organ made of distinct regions such as the root tip, root meristem, differentiation and elongation zones, and emerging lateral roots (Scheres et al., 2002). These regions have distinct roles. For instance, root hairs are differentiated epidermal cells important for plant mineral nutrition, as inferred from gene expression studies (Lauter et al., 1996; von Wiren et al., 2000) and nutrient accumulation measurements (Ahn et al., 2004). Root functional specificity is also reflected at the level of plant-microbe interactions. In Fabaceae for example, the root tip is the most important region to initiate the rhizobial colonization process leading eventually to the formation of a root nodule (Desbrosses and Stougaard, 2011). In Poaceae, root hairs and lateral roots are preferentially colonized by PGPR, where they may express their plant beneficial properties (Pothier etal., 2007; Combes-Meynet etal., 2011). Root system architecture (RSA) integrates root system topology, the spatial distribution of primary and lateral roots, and the number and length of various types of roots. Several abiotic and biotic factors can influence RSA, including PGPR strains. PGPR modify RSA and the structure of root tissues mainly through their ability to interfere with the plant hormonal balance (Figure 1). 


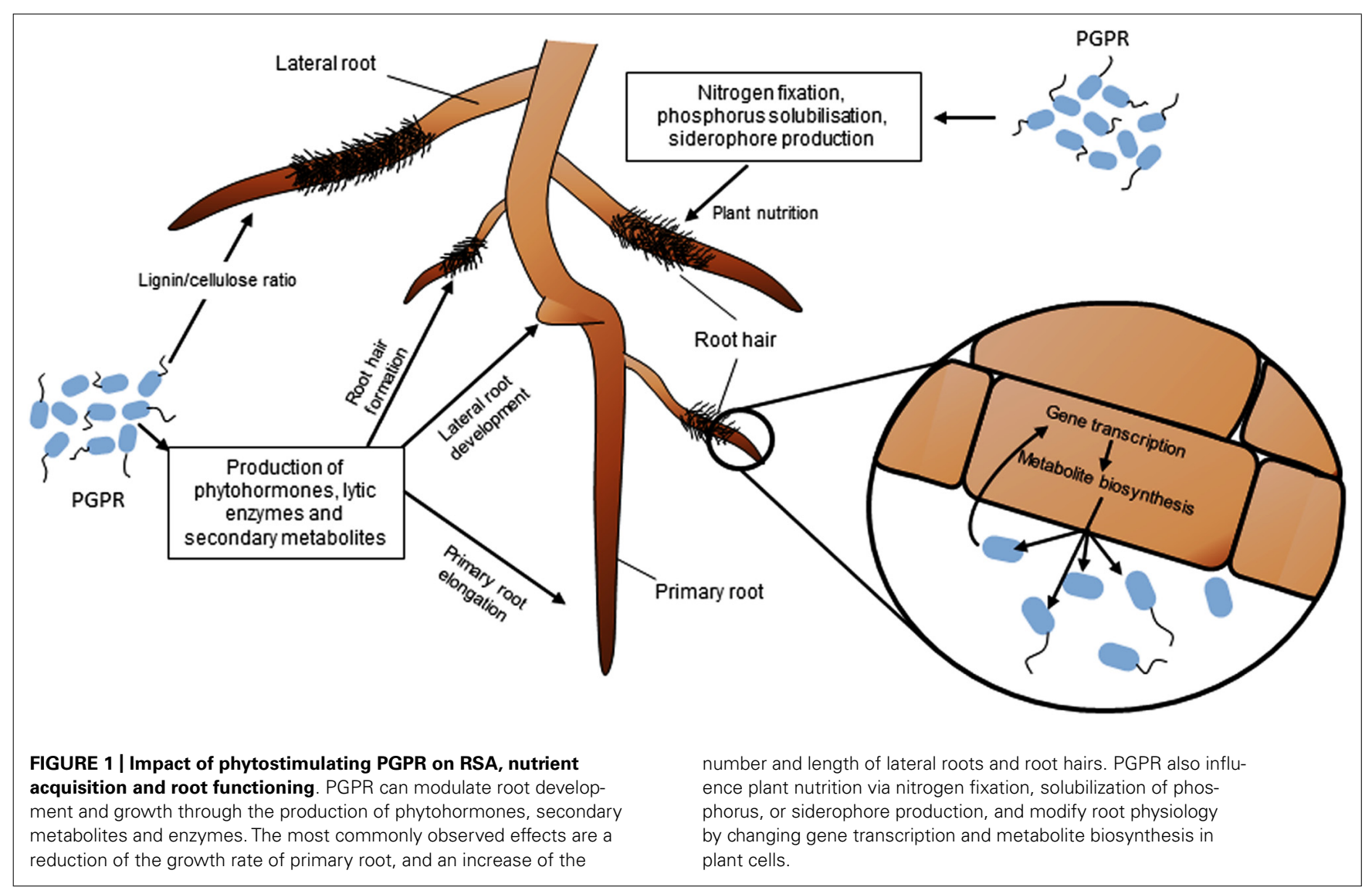

\section{PGPR EFFECTS ON RSA VIA MODULATION OF HOST HORMONAL BALANCE}

Changes in RSA may result from interferences of PGPR with the main hormonal pathways involved in regulating plant root development: auxin, cytokinin, ethylene, and to a lesser extend gibberellin, and abscisic acid (ABA) (Moubayidin et al., 2009; Stepanova and Alonso, 2009; Dodd et al., 2010; Overvoorde et al., 2011). The balance between auxin and cytokinin is a key regulator of plant organogenesis, and shapes root architecture (Aloni et al., 2006). The auxin to cytokinin ratio can be affected by PGPR because they are able to produce a wide range of phytohormones, including auxins and/or cytokinins, and secondary metabolites that can interfere with these hormonal pathways.

Many PGPR are able to produce phytohormones and secondary metabolites interfering with the plant auxin pathway, such as auxins, 2,4-diacetylphloroglucinol (DAPG), and nitric oxide (NO). Indole-3-acetic acid (IAA) is the best-characterized auxin produced by many plant-associated bacteria, including PGPR (Spaepen etal., 2007a). Exogenous IAA controls a wide variety of processes in plant development and plant growth: low concentrations of IAA can stimulate primary root elongation, whereas high IAA levels stimulate the formation of lateral roots, decrease primary root length and increase root hair formation (Figure 1; Dobbelaere et al., 1999; Patten and Glick, 2002; Perrig et al., 2007; Spaepen et al., 2007b; Remans et al., 2008). IAA is usually synthesized by rhizobacteria from tryptophan, which is found at different concentrations in root exudates according to plant genotype (Kamilova et al., 2006). In PGPR strains, several IAA biosynthetic pathways have been described depending on the metabolic intermediates (Spaepen et al., 2007a). The indole3-pyruvate decarboxylase (encoded by the ipdC/ppdC bacterial gene) is a key enzyme involved in the indolepyruvic acid pathway. Effects of ipdC mutants on plant root morphology are often altered in comparison to those of wild-type strains (Brandl and Lindow, 1998; Dobbelaere et al., 1999; Patten and Glick, 2002; Suzuki et al., 2003; Malhotra and Srivastava, 2008).

Plant growth promotion by PGPR can also result from indirect stimulation of the plant auxin pathway. For example, several PGPR strains like Azospirillum brasilense have a nitrite reductase activity and consequently are able to produce NO during root colonization (Creus et al., 2005; Pothier et al., 2007; Molina-Favero et al., 2008). NO is involved in the auxin signaling pathway controlling lateral root formation (Creus et al., 2005; Lanteri et al., 2006, 2008; Molina-Favero et al., 2008). DAPG is a well-known antimicrobial compound produced by biocontrol fluorescent pseudomonads (Couillerot et al., 2009). At lower concentrations, DAPG can also be a signal molecule for plants, inducing systemic resistance (Iavicoli et al., 2003; Bakker et al., 2007), stimulating root exudation (Phillips et al., 2004), and enhancing root branching (Brazelton et al., 2008; Couillerot et al., 2011; Walker etal., 2011). DAPG can interfere with an auxin-dependent signaling pathway and thus modify RSA (Brazelton et al., 2008). Indeed, applications of exogenous DAPG, at a concentration around $10 \mu \mathrm{M}$, inhibited primary root growth and stimulated lateral root production in tomato 
seedlings. Furthermore, roots of an auxin-resistant diageotropica mutant of tomato displayed reduced DAPG sensitivity (Brazelton et al., 2008).

The growth-promotion effect of auxin or auxin-like compounds by PGPR may require functional signaling pathways in the host plant. To test that hypothesis, one could use a host plant defective at a particular step of the hormone-signaling pathway and assess whether PGPR inoculation complements or not the effect of the mutation. This strategy requires the use of model plant such as Arabidopsis, the only biological system that provides to date enough documented mutant plants (Dubrovsky et al., 1994; Alonso et al., 2003). Consistent with that, some Arabidopsis auxin-signaling mutants failed to show the typical root architecture changes in response to the beneficial rhizobacterium Phyllobacterium brassicacearum STM196 (Contesto et al., 2010). However, auxin content was not increased in roots upon inoculation with Phyllobacterium brassicacearum STM196, ruling out the potential implication of auxin of bacterial origin (Contesto et al., 2010). Nevertheless, the use of Arabidopsis DR5::GUS reporter line, whose expression is restricted to the root meristem where the auxin maximum is located (Ulmasov et al., 1997; Casimiro et al., 2001), showed a change of expression pattern in response to STM196 inoculation (Figure 2). GUS staining appeared more intense on a wider region of the root tip as well as in the vasculature, suggesting that there was a change of auxin distribution in the root in response to STM196 inoculation, even though this strain is a low auxin producer (Contesto et al., 2010). Interestingly, a similar observation was made when Arabidopsis plantlets were inoculated with the PGPR Bacillus subtilis GB03 (Zhang et al., 2007), which emits volatile organic compounds (VOCs), or with Pseudomonas fluorescens WCS417 (Zamioudis et al., 2013).

Cytokinin production (especially zeatin) has been documented in various PGPR like Arthrobacter giacomelloi, Azospirillum brasilense, Bradyrhizobium japonicum, Bacillus licheniformis, Pseudomonas fluorescens, and Paenibacillus polymyxa (Cacciari et al., 1989; Timmusk et al., 1999; de García Salamone et al., 2001; Perrig et al., 2007; Cassán et al., 2009; Hussain and Hasnain, 2009). Cytokinins stimulate plant cell division, control root meristem differentiation, induce proliferation of root hairs, but inhibit lateral root formation and primary root elongation (Silverman et al., 1998; Riefler et al., 2006). Inoculation of plants with bacteria producing cytokinin has been shown to stimulate shoot growth and reduce the root to shoot ratio (Arkhipova etal., 2007). Bacterial genes involved in cytokinin biosynthetic pathways have been identified in silico but their role has not yet been validated through functional analyses (Frébort et al., 2011). Consequently, the contribution of cytokinin production by PGPR to RSA modifications remains speculative.
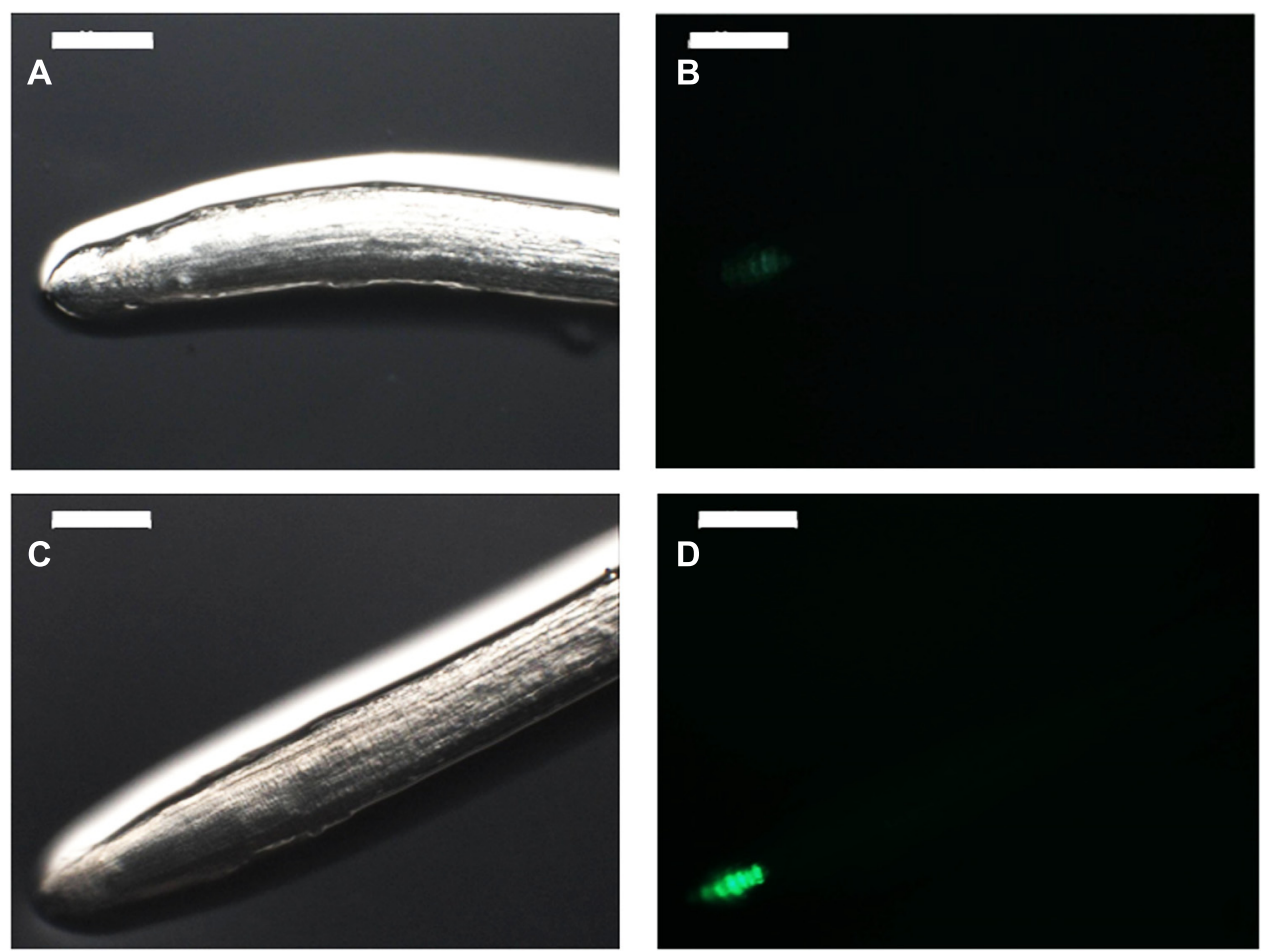

FIGURE 2 | PGPR-mediated changes in RSA may relate to modifications of auxin content in roots. Six-day-old Arabidopsis plantlets expressing the GFP gene under the control of the auxin-sensitive DR5 artificial promoter were inoculated (C, D) or not (A, B) with the PGPR Phyllobacterium brassicacearum STM196. Six days later, root tips were observed under normal light $(\mathbf{A}, \mathbf{C})$ or UV light (B, D) with a microscope (Z16APO, Leica,
Bensheim, Germany). Scale bars represent $200 \mu \mathrm{m}$. Inoculation by STM196 modified root traits such as root hair elongation and primary root growth, which coincided with an increase in GFP signal in the root tip in inoculated (D) compared with control plants (B). These observations confirm previous results with a different Arabidopsis DR5 reporter line (Contesto etal., 2010). 
Ethylene is another key phytohormone, which inhibits root elongation and auxin transport, promotes senescence and abscission of various organs, and leads to fruit ripening (Bleecker and Kende, 2000; Glick et al., 2007). Ethylene is also involved in plant defense pathways (Glick et al., 2007). This phytohormone can be produced in small amounts from the precursor methionine by some PGPR, like Azospirillum brasilense (Thuler et al., 2003; Perrig et al., 2007). The ability of Azospirillum brasilense to produce ethylene presumably promotes root hair development in tomato plants. Indeed, exogenous ethylene supply to the plant mimicked the effect of Azospirillum brasilense inoculation, while the addition of an ethylene biosynthesis inhibitor blocked this effect (Ribaudo et al., 2006). Actually, PGPR are more widely able to lower plant ethylene levels through deamination of 1-aminocyclopropane-1carboxylic acid (ACC). Many genomes of PGPR do contain a gene $(a c d S)$ coding for an ACC deaminase, which degrades ACC into ammonium and $\alpha$-ketobutyrate (Blaha et al., 2006; Contesto et al., 2008; Prigent-Combaret et al., 2008). By lowering the abundance of the ethylene precursor ACC, the PGPR AcdS activity is thought to decrease root ethylene production, which can in turn alleviate the repressing effect of ethylene on root growth (Glick, 2005). Despite being widely accepted and supported by experimental data (Penrose et al., 2001; Contesto et al., 2008), the model raises issues that have not been well addressed yet. The first one deals with ethylene production within roots. Light is promoting ethylene biosynthesis, providing there is a sufficient $\mathrm{CO}_{2}$ supply for shoots (Yang and Hoffman, 1984). Exposition of roots to light was shown to trigger an increase in ethylene production (Lee and Larue, 1992). In soil however, roots are sheltered from light, suggesting that this organ might not be able to synthesize large amounts of ethylene. In agreement with that, Fabaceae roots did produce ethylene in response to rhizobial colonization in presence of light, but less when they were in the dark (Lee and Larue, 1992). Secondly, there is a regulation of ethylene synthesis by a feedback loop (Yang and Hoffman, 1984). This loop should stimulate ethylene biosynthesis when the level of ACC is low. Unless PGPR disconnect that feedback loop, lowering ACC content would eventually result in stimulation of ethylene production. There is no indication yet how the feedback loop would work in presence of a PGPR. Last but not least, if ethylene plays a key role during the plant-PGPR interaction, one would expect that either plant ethylene mutants or impaired AcdS activity in the bacteria would result in clear disturbance of the plant responses to bacteria. However, minor effects on RSA were observed when plants were inoculated with an acdS bacterial mutant, or when plants affected in their ethylene signaling pathway were inoculated with wild-type PGPR (Contesto et al., 2008; Galland et al., 2012; Zamioudis et al., 2013). It suggests that ethylene participates to the root architecture response but is not a key player. Taken together, the functional importance of the bacterial ACC deaminase function needs further clarification. One hypothesis could be that AcdS contributes to the fine-tuning of ethylene biosynthesis during the plant-PGPR cooperation.

Several reports have revealed that PGPR are able to produce ABA or gibberellic acid, or to control the level of these hormones in plants (Richardson et al., 2009; Dodd et al., 2010). The first one, ABA, is well known for its involvement in drought stress. During water stress, increase in ABA levels causes closing of stomata, thereby limiting water loss (Bauer et al., 2013). However, this hormone also plays different roles during lateral root development (De Smet et al., 2006; Dodd et al., 2010). Inoculation with Azospirillum brasilense Sp245 led to an increase of ABA content in Arabidopsis, especially when grown under osmotic stress (Cohen et al., 2008). Gibberellins promote primary root elongation and lateral root extension (Yaxley et al., 2001). Production of gibberellins has been documented in several PGPR belonging to Achromobacter xylosoxidans, Acinetobacter calcoaceticus, Azospirillum spp., Azotobacter spp., Bacillus spp., Herbaspirillum seropedicae, Gluconobacter diazotrophicus and rhizobia (Gutiérrez-Mañero et al., 2001; Bottini et al., 2004; Dodd et al., 2010). Application of gibberellic acid on maize, at a concentration similar to that produced by Azospirillum, promotes root growth; furthermore, gibberellin content increases in maize root inoculated with Azospirillum (Fulchieri et al., 1993). In addition to playing a role in plant RSA, these two hormones are involved in plant defense mechanisms. Thus, PGPR producing these hormones may modulate the hormonal balance involved in plant defense, including the jasmonate and salicylic acid pathways (for a review see Pieterse et al., 2009).

Although the production of hormones by PGPR has been well described, the genetic determinants involved in their biosynthesis remain largely unknown and bacterial mutants affected in hormone biosynthesis are mostly lacking. Consequently, the involvement of hormones of bacterial origin in the modulation of plant hormonal balance has not been fully demonstrated.

\section{MODIFICATION OF ROOT CELL WALL AND ROOT TISSUE STRUCTURAL PROPERTIES BY PGPR}

Many PGPR can lead to modifications of the chemical composition and therefore structural properties of root cell walls (Figure 1; El Zemrany et al., 2007; Zhang et al., 2007). For example, the biocontrol agent Bacillus pumilus INR-7 is able to enhance lignin deposition in pearl millet epidermal tissues, and this plant defense response appears much more rapidly in PGPR-primed plants infected by the pathogen Sclerospora graminicola compared to nonprimed plants (Niranjan Raj et al., 2012). The sole inoculation of INR-7 led to callose apposition. Although the precise location of these deposited polymers was not investigated, it is possible that their enhanced accumulation may participate to pathogen inhibition and disease suppression. A similar response was also triggered by Bacillus pumilus SE34 and Bacillus subtilis UMAF6639 when inoculated to respectively pea and melon roots. In both cases, it led to enhanced fungal pathogen tolerance (García-Gutiérrez et al., 2013). Inoculation of Pseudomonas fluorescens 63-28R to pea roots induced accumulation of lignin in root cells and inhibited colonization by the oomycete Pythium ultimum (Benhamou et al., 1996). The same result was observed with a Pseudomonas putida strain inoculated on bean roots (Anderson and Guerra, 1985). These cell wall modifications have been reported in the case of PGPR that protect plants against phytopathogens by activating ISR plant defense responses (Iavicoli et al., 2003; Desoignies et al., 2012; Weller et al., 2012; García-Gutiérrez et al., 2013). One of the consequences of ISR is thus the reinforcement of the cell wall through enhanced lignin synthesis and callose apposition (Kovats et al., 1991; Strömberg and Brishammar, 1993), which 
restricts the progression of phytopathogens through plant tissues (García-Gutiérrez et al., 2013).

Modifications of the chemical composition of root cell walls are also triggered by PGPR that directly promote plant growth (Figure 1). Through the analysis of the infrared spectral characteristics of crude cell wall preparations of maize roots, El Zemrany et al. (2007) concluded that roots inoculated with Azospirillum lipoferum CRT1 had lower lignin content than uninoculated ones. This result contrasts with those aforementioned for biocontrol agents. Nevertheless, lower lignin content may facilitate cell elongation, and therefore overall root elongation. Similarly, Azospirillum irakense produces pectate lyases that are capable of degrading the pectate content of root cell wall and might allow its progression between root cortex cells and its functioning as an endophyte (Bekri et al., 1999). Up to now, the impact on plant lignin content of PGPR that are both inducing ISR and promoting root growth has not been clarified.

Modifications of root cell wall ultrastructure are thought to result mainly from PGPR-triggered changes in plant gene expression. Indeed, Bacillus subtilis GB03 promotes Arabidopsis growth by producing VOCs that were shown to modulate the expression of 38 genes with known functions associated with cell wall structure (Ryu et al., 2003; Zhang et al., 2007). Among them, 30 were implicated in cell wall expansion or loosening. The endophytic PGPR Azospirillum irakense was also shown to stimulate the expression of polygalacturonase genes in inoculated rice roots (Sekar et al., 2000).

Chemical mediators involved in the effects of PGPR on root cell walls have received little attention. A single report has indicated that the exogenous addition of auxins enhanced the induced polygalacturonase activities observed in Azospirillum irakense inoculated rice roots (Sekar et al., 2000).

\section{SYSTEMIC EFFECTS OF PGPR ON WHOLE PLANT PHYSIOLOGY AND FUNCTIONING}

In addition to their effects on root tissues, PGPR can modify the physiology and functioning of plant tissues located at a substantial distance from the colonized sites, such as shoots. Two types of mechanisms are involved. On the one hand, some PGPR can enhance nutrient availability/uptake for plant roots. Stimulation of plant nutrition will lead to modifications in primary metabolism and consequently will contribute to enhance growth. On the other hand, certain PGPR trigger specific systemic responses, mostly by unknown signaling mechanisms. Highthroughput analyses of plant transcriptomic and metabolomic responses have evidenced the effects of PGPR on plant gene expression and metabolite accumulation, respectively. These results highlight the extensive effect of PGPR on whole plant physiology and functioning (Figure 1), and provide clues to understand the systemic effect of PGPR.

\section{IMPACT OF PGPR ON PLANT NUTRITION}

The impact of PGPR on plant nutrition may result from effects on plant nutrient uptake and/or on plant growth rate (Mantelin and Touraine, 2004). It is indeed commonly hypothesized that nutrient uptake is increased as a consequence of increased root surface area triggered by PGPR. However, root ion transporters are under the control of regulatory processes that adjust their activity to the plant nutritional demand (Imsande and Touraine, 1994; Lappartient and Touraine, 1996; Lappartient et al., 1999; Nazoa et al., 2003), so that regulations of root development and ion transporter activities are antagonistically coordinated to maintain steady nutrient acquisition rate (Touraine, 2004). Hence, PGPR must interfere with pathways coordinating plant development and plant nutrition to elicit both increased nutrient acquisition rate and plant growth promotion (Figure 1).

Plant growth-promoting rhizobacteria can directly increase nutrient supply in the rhizosphere and/or stimulate ion transport systems in root. With regards to increased nutrient supply, two main types of bacterial activities can be considered. Firstly, phosphate solubilization is one key effect of PGPR on plant nutrition. Soils generally contain a large amount of phosphorus, which accumulates in the wake of regular fertilizer applications, but only a small proportion of the latter is available for plants. Plants are able to absorb on their own mono and dibasic phosphate; organic or insoluble forms of phosphate need to be mineralized or solubilized by microorganisms, respectively (Richardson et al., 2009; Ramaekers et al., 2010). Many PGPR - such as Pseudomonas, Bacillus, Rhizobium - are able to dissolve insoluble forms of phosphate (for a review see Richardson etal., 2009). Two main processes exist: acidification of the external medium through the release of low molecular weight organic acids (such as gluconic acid) that chelate the cations bound to phosphate (Miller et al., 2009), and production of phosphatases/phytases that hydrolyse organic forms of phosphate compounds. Secondly, many associated bacteria can fix $\mathrm{N}_{2}$ so that they could provide nitrogen to the plant. Evidence in favor of the participation of PGPR to the plant $\mathrm{N}$ budget has been reported for several plants, especially sugar cane (Boddey et al., 2003). However, the impact of $\mathrm{N}_{2}$-fixation by PGPR is still debated and is rarely credited for the stimulation of plant growth (for review see Dobbelaere et al., 2003). In addition, non-fixing rhizobacteria can promote plant growth, showing that $\mathrm{N}$ provision is not obligatory for plant growth promotion. For instance, Phyllobacterium brassicacearum STM196 is unlikely to fix $\mathrm{N}_{2}$ while it promotes the growth of canola and Arabidopsis (Bertrand et al., 2000, 2001; Mantelin et al., 2006).

With regards to the impact of PGPR on nutrient uptake systems, only very few studies have been published so far. Inoculation of canola with Achromobacter sp. strain U80417 resulted in an increase of both $\mathrm{NO}_{3}^{-}$and $\mathrm{K}^{+}$net influx rates per root surface area unit (Bertrand et al., 2000). In this study, the net $\mathrm{H}^{+}$efflux was also enhanced, so that increased $\mathrm{NO}_{3}^{-}$and $\mathrm{K}^{+}$uptake rates may be part of a general mechanism leading to increased ion uptake rate, similar to energization of nutrient transport by enhanced proton pump activity (Sondergaard et al., 2004). In favor of this hypothesis, acidification of the rhizosphere has also been reported with Arabidopsis exposed to the VOC-emitting Bacillus subtilis strain GB03 (Zhang et al., 2009).

In Arabidopsis, $\mathrm{NO}_{3}^{-}$uptake measurement in response to PGPR, over time, can lead to contradictory results: $\mathrm{NO}_{3}^{-}$influx was increased in seedlings, upon 24 h-inoculation with Phyllobacterium brassicacearum STM196, while it was reduced 7 days later (Mantelin et al., 2006). However, it is hard to draw a firm conclusion as the net $\mathrm{NO}_{3}^{-}$uptake rate remained unknown since ion 
efflux was not measured in these experiments. Except for the NRT2.5 and NRT2.6 genes, the accumulation of transcripts of nitrate and ammonium transporters was very slightly or not significantly changed upon Phyllobacterium brassicacearum STM196 inoculation (Mantelin et al., 2006). Interestingly, these two genes have recently been shown to be required in Arabidopsis growth promotion by this PGPR (Kechid et al., 2013). Since these two genes code for two plasma membrane-localized $\mathrm{NO}_{3}^{-}$transporters (Kotur etal., 2012), this discovery raises the question of the interactions between $\mathrm{N}$ nutrition and plant development in PGPR-inoculated plants. The NRT2.5 and NRT2.6 genes are predominantly expressed in shoots (Mantelin et al., 2006). Their role in Phyllobacterium brassicacearum STM196 plant growth promotion and/or root architecture modification are not linked to changes in $\mathrm{NO}_{3}^{-}$uptake rate or $\mathrm{NO}_{3}^{-}$distribution between roots and shoots (Kechid etal., 2013), suggesting an involvement in $\mathrm{N}$-signaling rather than a direct role in $\mathrm{N}$-metabolism.

Evidence in favor of a regulation of ion transporters at a transcriptional level by PGPR has been obtained in studies with Bacillus subtilis GB03. This strain induces concomitant downand up-regulation of HKT1 expression in roots and shoots of Arabidopsis seedlings, respectively (Zhang et al., 2008). In the shoots, HKT1 functions in phloem tissues to retrieve $\mathrm{Na}^{+}$from the xylem (Berthomieu et al., 2003) and in the roots it is involved in $\mathrm{Na}^{+}$ uptake (Rus etal., 2001). The differential regulation of HKT1 expression in roots and shoots resulted in reduced accumulation of $\mathrm{Na}^{+}$and increased accumulation of $\mathrm{K}^{+}$in both organs of GB03-inoculated seedlings under salt-stress conditions (Zhang et al., 2008). Consistent with the effect of GB03 on HKT1, GB03 failed to rescue salt-stressed $h k t 1$ mutant seedlings from elevated $\mathrm{Na}^{+}$accumulation.

Volatile organic compounds emitted by GB03 also activate the plant's iron acquisition machinery leading to increased iron assimilation (Zhang et al., 2009). Firstly, this PGPR leads to acidification of the rhizosphere, both directly due to chemical effects of some unidentified VOCs and indirectly through increased root proton efflux. Secondly, GB03 up-regulates the expression levels of FRO2 and IRT1 genes, coding respectively for a $\mathrm{Fe}^{3+}$ chelate reductase and a $\mathrm{Fe}^{2+}$ transporter. As a result, GB03-exposed Arabidopsis has enhanced ferric chelate reductase activity and increased iron content. Finally, it has been shown that this PGPR induces the expression of the FIT1 transcription factor that regulates positively FRO2 and IRT1 expressions (Zhang et al., 2009). The fact that GB03 fails to increase root ferric reductase activity and plant iron content in Arabidopsis fit1 mutants shows that PGPR can modify indirectly ion uptake by interfering with plant regulatory processes that control ion transporter expressions and/or activities (Zhang et al., 2009).

\section{IMPACT OF PGPR ON PLANT TRANSCRIPTOME}

Targeted or genome-wide analyses of plant gene expression following root inoculation by PGPR were reported with various bacterial models: phytostimulating PGPR, endophytes and PGPR exerting a biocontrol activity. Inoculation of the phytostimulator Pseudomonas putida MTCC5279 triggered overexpression of 520 genes and repression of 364 genes (threefold changes) in leaves of Arabidopsis; upregulated genes were involved in maintenance of genome integrity, growth hormone and amino acid syntheses, ABA signaling and ethylene suppression, $\mathrm{Ca}^{2+}$ dependent signaling and induction of ISR (Srivastava et al., 2012). On rice, a recent study performed with Azospirillum points towards association specificity (Vargas et al., 2012). The targeted expression of ethylene receptors was followed after inoculation of Azospirillum brasilense Sp245 on two rice cultivars of contrasted ability to gain nitrogen from biological nitrogen fixation. Seedlings of cultivar IR42, which enabled higher nitrogen fixation, also displayed higher expression of ethylene receptors compared to cultivar IAC 4440 (Vargas et al., 2012). The transcript accumulation of all ethylene receptors might be necessary for the establishment of a beneficial association between the plant and the bacteria.

As for endophytes, differential colonization of rice roots was observed with an Azoarcus PGPR. In a less compatible interaction, a slight defense response occurred and was accompanied by the induction of pathogenesis-related proteins and proteins sharing domains with receptor-like kinases induced by pathogens; those proteins were also induced by a jasmonate treatment (Miché et al., 2006). Inoculation of rice roots with the endophytic PGPR Herbaspirillum seropedicae triggered the expression of genes responsive to auxin and ethylene and the repression of the defense-related proteins PBZ1 and thionins (Brusamarello-Santos et al., 2012). These studies suggest that endophytes modulate plant defense responses during colonization.

Plants treated with biocontrol PGPR, usually belonging to the Pseudomonas genus, are more resistant to subsequent infections by bacterial or fungal pathogens. In Arabidopsis, this rhizobacteriamediated ISR requires sensitivity to jasmonate and ethylene, and the regulators MYC2 (Pieterse et al., 1996, 2000; Pozo et al., 2008), NPR1 (Pieterse et al., 1998), and MYB72 (Van der Ent et al., 2008) played a central role in this signaling. One of the earliest transcriptomic study performed with Pseudomonas fluorescens WCS417r indicated that bacteria elicited a substantial change in the expression of 97 genes in roots whereas none of the approximately 8,000 genes tested showed a consistent change in expression in the leaves (Verhagen et al., 2004). Subsequent studies on Arabidopsis reported an increase of defense-related transcripts, including PR-related proteins, in shoots of bacterized plants compared to untreated shoots (Cartieaux et al., 2003; Wang et al., 2005; van de Mortel et al., 2012). Interestingly, the ISR induced by Pseudomonas fluorescens SS101 was recently reported to be dependent on salicylic acid signaling and not on jasmonic acid and ethylene signaling (van de Mortel et al., 2012); moreover, a prominent role of camalexin and glucosinolates in the ISR was proposed. In wheat, bacterization with Pseudomonas fluorescens Q8r1-96 also triggered the accumulation of defense-related transcripts (Okubara et al., 2010; Maketon et al., 2012) and neither DAPG nor the type three secretion system were key single factors in the expression of these genes (Maketon et al., 2012). The establishment of beneficial associations requires mutual recognition and substantial coordination of plant and microbial responses and consequently beneficial microbes modulate plant immunity.

\section{IMPACT OF PGPR ON PLANT METABOLOME}

Several studies have addressed the metabolomic changes triggered by PGPR inoculation, by analyzing metabolite contents of root 
exudates, root tissues and shoots under normal or stressful conditions (Figure 1). Some studies have shown that PGPR can elicit changes in the activities of root enzymes involved in the production of metabolites, especially flavonoids, leading to changes in the pattern of root exudation (Lavania et al., 2006; Shaw et al., 2006). Some Azospirillum PGPR stimulated by up to one-third the level of carbon compounds exuded from roots (Heulin et al., 1987). Moreover, compounds of microbial origin, such as phenazines and DAPG, could enhance total net efflux of amino acids in plant species (Phillips et al., 2004). On soybean roots, the PGPR Chryseobacterium balustinum Aur9 influences flavonoids exudation (Dardanelli et al., 2010). PGPR strains from Chryseobacterium (Dardanelli et al., 2010) or Azospirillum (Burdman et al., 1996) may influence flavonoid exudation by Fabacea roots. This property can be important for the design of mixed inoculants that will include a PGPR strain promoting flavonoid exudation together with rhizobia that will respond to plant flavonoids (Burdman et al., 1996).

In addition to effects on root exudates, PGPR can trigger modifications of metabolite composition of the whole plant. For instance, rice plants inoculated with Herbaspirillum seropedicae showed higher shoot contents in malate and in key amino acids than those of control plants (Curzi et al., 2008). Many more studies focused on modifications of secondary metabolites. Elicitation of isoflavone accumulation was observed on soybean inoculated with various PGPR, either by increasing the total isoflavone content in seedlings or by causing an asymmetric distribution of isoflavones throughout the plant (Ramos-Solano et al., 2010). Increase in the content of several alkaloid and terpenoid compounds of pharmaceutical relevance was demonstrated in medicinal plants following PGPR inoculation (Manero et al., 2003; Jaleel et al., 2007; Bharti et al., 2013). Recent studies investigated the early impact of several Azospirillum strains on root and shoot secondary metabolite profiles of maize and rice; analysis of secondary metabolites of two maize cultivars, inoculated by three different Azospirillum strains under greenhouse conditions, revealed major qualitative and quantitative modifications of the contents of secondary metabolites, especially benzoxazinoids (Walker et al., 2011). In the same way, a metabolic profiling approach of two rice cultivars inoculated with two different Azospirillum strains under gnotobiotic conditions, showed that profiles of secondary metabolites were modified with phenolic compounds such as flavonoids and hydroxycinnamic derivatives being the main metabolites affected (Chamam et al., 2013). Both studies evidenced a specific response, as plant metabolic changes differed according to the Azospirillum strain-cultivar combination. Moreover, PGPR applied to the roots can affect the composition of secondary metabolites in shoots, pointing towards systemic effects (Chamam et al., 2013).

Accumulation of secondary compounds was also modified in several plants inoculated with consortia containing arbuscular mycorrhizal fungus and PGPR. Blumenin accumulation triggered by Rhizophagus irregularis (formerly Glomus intraradices) in barley and wheat roots was increased when a rhizosphere bacterium was applied with the fungus (Fester et al., 1999). Leaf secondary metabolites (total phenols and ortho dihydroxy phenols), as well as leaf mineral content (phosphorus, potassium, zinc, copper, and iron) were maximal when Begonia malabarica or Solanum viarum were inoculated with consortia containing two fungi and a Bacillus coagulans strain (Selvaraj et al., 2008; Hemashenpagam and Selvaraj, 2011). Field-inoculation of maize with selected strains of Pseudomonas, Azospirillum or Rhizophagus/Glomus, or with these strains combined two by two or all three together, led to qualitative and quantitative modifications of root secondary metabolites, particularly benzoxazinoids and diethylphthalate (Walker et al., 2012). These modifications depended on fertilization level and on the type of microorganisms inoculated. The three selected strains gave distinct results when used alone, but unexpectedly all microbial consortia gave somewhat similar metabolic responses.

Plant growth-promoting rhizobacteria can help plants to withstand saline stress, a feature that may be linked to accumulation of specific metabolites. A higher level of proline content was reported in inoculated Bacopa monnieri (Bharti et al., 2013), as well as higher accumulation of glycine betaine-like quaternary compounds in rice inoculated with Pseudomonas pseudoalcaligenes (Jha et al., 2011). Similarly, Arabidopsis inoculation with the VOC-emitting strain Bacillus subtilis GB03 induced strong plant accumulation of glycine betaine and its precursor choline, and GB03-induced drought tolerance was lost in the xipotl mutant of Arabidopsis with reduced choline production (Zhang et al., 2010). Alleviation of cold stress was demonstrated for Burkholderia phytofirmans PsJN on grapevine; this endophytic strain promotes plant post-chilling recovery by improving acclimation to cold (Ait Barka etal., 2006). This is accompanied by accumulation of stress-related metabolites such as proline, malondialdehyde and aldehydes (known as lipid peroxidation markers), hydrogen peroxide, and by higher expression of defense- and cold-related genes (Theocharis et al., 2012). Bacterization resulted in a 1.2-fold increase in starch content and in a two-fold increase in total soluble sugars, with sugars known to be involved in low-temperature tolerance (glucose, sucrose, and raffinose) displaying higher concentrations in treated plantlets (Fernandez et al., 2012). Independently of temperature, inoculation also enhanced phenolic content (Ait Barka et al., 2006).

\section{EXPRESSION OF PLANT-BENEFICIAL FUNCTIONS OF PGPR IN THE RHIZOSPHERE}

One PGPR strain can harbor several plant-beneficial properties, which may be co-regulated or not. Within the rhizosphere, the expression of PGPR's plant-beneficial properties is affected by both abiotic factors (like $\mathrm{pH}$, oxygen, clay mineralogy, heavy metals, etc.) and biotic factors (i.e., compounds produced by plants or the rhizo-microbiome) that can lead to distinct expression patterns in space and time, possibly with different effects on host plant (Piccoli and Bottini, 1994; Pothier et al., 2008; Prigent-Combaret et al., 2008; Dutta and Podile, 2010; Almario et al., 2013b; Drogue et al., 2013). In this section, a focus is put on the regulation of the expression of PGPR plant-beneficial properties by biotic factors occurring in the rhizosphere.

\section{REGULATION OF PGPR FUNCTIONS BY ROOT EXUDATES}

Through the release of root exudates, plants can impact bacterial gene expression, especially genes encoding plant-beneficial traits. Composition of root exudates is dependent upon intra and inter-specific genetic variability (Bertin et al., 2003; Czarnota et al., 
2003; Phillips et al., 2004), plant developmental stage (Lynch and Whipps, 1990; Bacilio-Jiménez et al., 2003) and soil abiotic factors (Lipton et al., 1987). One of the major studies aiming at analyzing the impact of root exudates variability on bacterial gene expression was carried out on phlA, involved in DAPG biosynthesis, in Pseudomonas protegens (formely Pseudomonas fluorescens) CHA0 (Notz et al., 2001). The expression of phlA was increased fourfold in the rhizosphere of monocots (maize and wheat) compared to the rhizosphere of dicots (bean and cucumber). The analysis of six maize cultivars also revealed that phl expression and hence biocontrol activity could be affected by plant genotype (Notz et al., 2001). Specific components of root exudates, notably sugars, were shown to affect the production of antimicrobial compounds, such as DAPG, pyoluteorin and pyrrolnitrin by fluorescent pseudomonads, with some strain-dependent effects (Duffy and Défago, 1999). Among 63 plant compounds related to defense or development, or involved in plant-microbe interactions (flavonoids, phenolic acids, phytohormones, etc.), many could modulate the expression of phlA and pltA in Pseudomonas protegens CHA0 (de Werra et al., 2011). No specific chemical structures were identified that generally induced or repressed phlA or pltA expression (de Werra et al., 2011). Umbelliferone led to the strongest inhibition of phlA; salicylate, jasmonate, and methyl jasmonate, all slightly reduced $p h l A$ expression, whereas the plant hormone IAA induced $p h l A$ expression. None of these compounds had an effect on pltA expression (de Werra et al., 2011) whereas a previous study reported repression of both DAPG and pyoluteorin biosynthesis genes by salicylate (Baehler et al., 2005).

1-Aminocyclopropane-1-carboxylic acid deamination (encoded by $a c d S$ ) is another bacterial function that may be differentially expressed according to plant genotypes. Indeed, in vitro experiments demonstrated that some compounds present in root exudates tightly control acdS expression. First, ACC, the precursor of ethylene that is metabolized by AcdS, can positively regulate acdS expression (Hontzeas et al., 2004; Prigent-Combaret et al., 2008). Second, leucine, by inhibiting oligomerization of the Lrptype regulator AcdR, prevents transcription of acdS leading to a decrease of ACC deaminase activity in Pseudomonas putida UW4 (Li and Glick, 2001) and in Azospirillum lipoferum 4B (PrigentCombaret et al., 2008). Finally, carbon sources can also influence acdS transcription (Prigent-Combaret et al., 2008).

As presented above, bacterial IAA biosynthesis mostly depends on tryptophan-related pathways (Spaepen etal., 2007a). The main source of tryptophan for PGPR is root exudates. Measurement of tryptophan bioavailability from graminaceous roots (Avena barbata) indicated that this amino acid is abundant at the emergence of secondary roots (Jaeger et al., 1999). In the absence of exogenous tryptophan supply, bacterial IAA biosynthesis is insignificant (Ona et al., 2005; Malhotra and Srivastava, 2006). Next to being an IAA precursor, tryptophan also plays an important role in regulating positively the $i p d C / p p d C$ gene (Ona et al., 2005). Other root-exuded amino acids like tyrosine and phenylalanine can also induce $i p d C / p p d C$ expression (Rothballer et al., 2005). Besides amino acids, plant roots release compounds like vitamins (e.g., pyridoxine and nicotinic acid) and organic acids (e.g., phenylacetic acid and prephenic acid; Shukla et al., 2011). All these compounds increase significantly IAA production in Azospirillum brasilense Sp245 (Zakharova etal., 2000; Somers et al., 2005).

Metabolites present in root exudates can thus specifically modulate the expression of key genes involved in plant-beneficial functions. Consequently, specific physiological responses of the plant are dependent on the PGPR strain/plant cultivar combination (Drogue et al., 2012).

\section{REGULATION OF PGPR FUNCTIONS BY MICROBIAL SIGNALS}

Plant growth-promoting rhizobacteria exchange several types of cell-to-cell communication signals between each other and with other rhizosphere-inhabiting bacteria and fungi, i.e., quorumsensing (QS) signals that allow bacteria to monitor their density and to coordinate gene expression only when a quorum of cells is achieved (Fuqua et al., 1994) and other bacterial signals that regulate gene expression independently of the cell density.

Quorum-sensing relies on the synthesis and perception of small diffusible molecules, such as $N$-acyl-homoserine lactones (AHLs). In fluorescent pseudomonads, colonization properties and biosynthesis of antimicrobial metabolites, such as phenazines, is often subjected to an AHL-based QS regulation (Pierson et al., 1994; Chin-A-Woeng et al., 2001; De Maeyer et al., 2011). Production of pyrrolnitrin in Serratia plymuthica HRO-C48, a strain isolated from the rhizosphere of oilseed rape and able to protect crops against Verticillium wilt, is also under QS regulation (Liu et al., 2007). In S. plymuthica G3, an endophytic strain, QS positively regulates antifungal activity, production of exoenzymes, but negatively regulates IAA production (Liu et al., 2011). Among the genus Azospirillum, only a few strains belonging to the lipoferum species and isolated from rice, display the ability to produce AHL signals (Vial et al., 2006). In the rice endophyte Azospirillum lipoferum B518, AHL inactivation abolishes pectinase activity, increases siderophore synthesis and reduces IAA production (in stationary phase) but no effect is observed on cellulase activity and on the phytostimulatory effect (Boyer et al., 2008). Moreover, a proteomic approach indicates that AHL-based QS regulation in Azospirillum is rather dedicated to control functions linked to rhizosphere competence and adaptation to plant roots (Boyer et al., 2008).

Interestingly, several studies have shown that bacterial communication of a specific bacterial population could be jammed by other microbes; indeed, some soil bacteria can inactivate AHL (notably members of the genus Bacillus), whereas others can intercept AHL or can act as a physical barrier preventing their diffusion (Boyer and Wisniewski-Dyé, 2009). Consequently, other members of the bacterial rhizosphere community can compromise expression of biocontrol traits in PGPR. Conversely, cross-talk between species using the same AHL signal or a structurally-related AHL can occur in natural habitats and was evidenced in the rhizosphere of wheat and tomato (Pierson et al., 1998; Steidle et al., 2001). Finally, plant compounds designated as AHL-mimics can also interfere with bacterial QS and may influence the expression of plant-beneficial functions (Teplitski et al., 2000; Vandeputte et al., 2010). Some Pseudomonas fluorescens strains unable to synthetize AHLs but possessing the cognate receptor may even recognize a plant compound to trigger expression of genes involved in biocontrol properties (Subramoni et al., 2011). 
Exometabolites produced by microbial populations including pathogenic fungal strains can also affect PGPR plant-beneficial properties. For instance, fusaric acid produced by Fusarium oxysporum represses the production of DAPG in the biocontrol strain Pseudomonas protegens CHA0 (Notz et al., 2002). Next to their antifungal effect, some Pseudomonas-produced compounds can influence gene expression of biocontrol traits in pseudomonads. Indeed, in Pseudomonas protegens strains CHA0 and Pf-5, DAPG and pyoluteorin productions are influenced by positive autoregulation; moreover, DAPG and pyoluteorin mutually inhibit one another's production (Brodhagen et al., 2004; Baehler et al., 2005). In order to determine if DAPG could act as a signal on other PGPR strains than those of the fluorescent Pseudomonas group, a differential fluorescence induction promoter-trapping approach based on flow cytometry was developed on Azospirillum. Using this approach DAPG was shown to enhance expression of a wide range of Azospirillum brasilense genes, including genes involved in phytostimulation. Four of them (i.e., ppdC, flgE, nirK, and nifX-nifB) were upregulated on roots in the presence of Pseudomonas fluorescens F113 compared with its DAPG-negative mutant (Combes-Meynet et al., 2011). Accordingly, Pseudomonas fluorescens F113 but not its DAPG-negative mutant enhanced the phytostimulatory effect of Azospirillum brasilense Sp245 on wheat. Thus, DAPG can act as a signal by which some beneficial pseudomonads may stimulate plant-beneficial activities of Azospirillum PGPR (Combes-Meynet et al., 2011). This finding is also relevant in the context of inoculation with microbial consortia, in which different types of PGPR may be combined. The number of studies investigating the efficacy of such combined inoculations is growing, with variations in the number of microorganisms and the nature of the combinations (PGPR strains only, PGPR and fungi, etc.; Cassán et al., 2009; Couillerot et al., 2012; Kumar et al., 2012; Walker et al., 2012). Field inoculation of sorghum with fluorescent Pseudomonas strains alone or in combination with arbuscular mycorrhizal fungi showed a better effect when in presence of the latter (Kumar et al., 2012). Field inoculation of maize with a consortium consisting of two PGPR (Azospirillum lipoferum CRT1 and Pseudomonas fluorescens F113) and one mycorrhizal strain (Rhizophagus irregularis/Glomus intraradices JJ291) showed an increase of root surface, root volume and number of roots, although data were not statistically significant compared to the single $R h i$ zophagus inoculation (Walker et al., 2012). Modification of one member of this consortium (three different Azospirillum strains were tested) could lead to significant modification of maize growth (Couillerot et al., 2012). Further studies are needed to describe the synergistic effects between beneficial microorganisms at a molecular scale and to analyse the expression of plant-beneficial functions when consortia are used.

\section{ECOLOGY OF PGPR POPULATIONS AND IMPACT ON ROOT SYSTEM FUNCTIONING}

Many studies have deciphered the mechanisms of action of PGPR using one individual strain and one host plant. But in reality, as described above, PGPR strains are not acting individually in the rhizosphere but rather as part of bacterial communities, in which cell communication signals may coordinate the activities of all individual strains. Indeed, a vast array of PGPR populations displaying co-occurring plant-beneficial activities and that may share between each other antagonistic or synergistic effects are interacting with a same host plant (Figure 3). When analysing plant growth-promoting effects, it is thus important to integrate the complexity of the interactions between PGPR populations within

\section{ABIOTIC FACTORS}

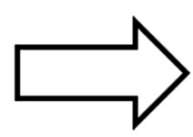

Soil composition Soil management Climatic factors

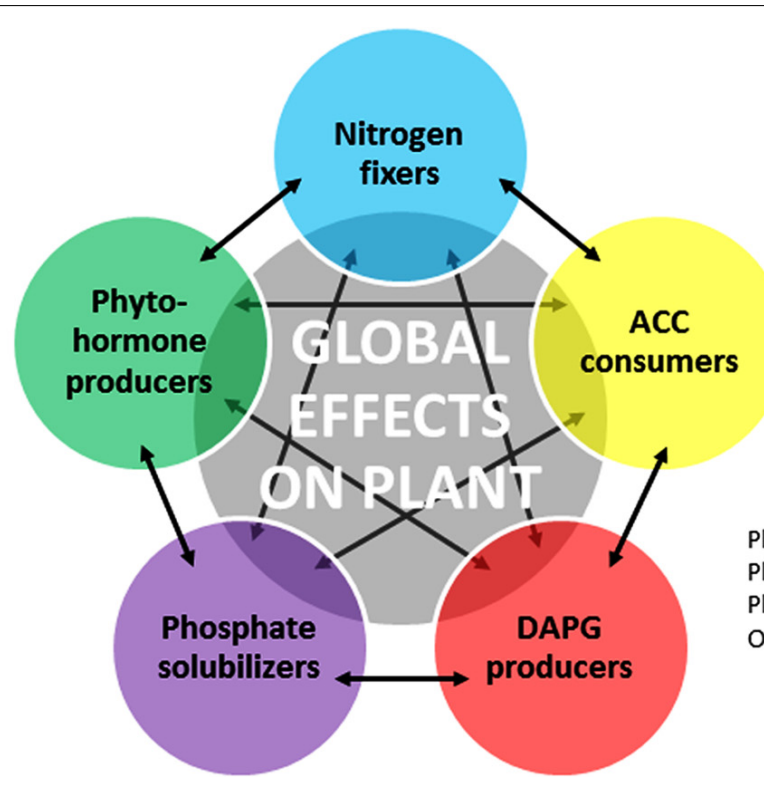

BIOTIC FACTORS

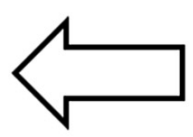

Plant genotypes

Plant developmental stages

Plant defense mechanisms

Other members of the microbial community
FIGURE 3 | Implementation of plant-growth promoting traits in PGPR functional groups. Selected PGPR functional groups are represented by different colored circles. The resulting effect of all PGPR functional groups on the plant is symbolized by the gray circle. Abiotic and biotic factors may influence the activity of each functional group. Solid arrows represent potential interactions (inhibition, signaling, etc.) between members of the functional groups, which may impact on the size, diversity and activity of these groups. 
the rhizo-microbiome. To do so, functional ecology approaches are needed, in which the relations between the size, diversity and activities of PGPR assemblages in the rhizosphere are taken into account. This is of particular importance when assessing the effect of various environmental factors, including that of plant genotype.

\section{PGPR ECOLOGY IN THE RHIZOSPHERE: FROM INDIVIDUAL STRAINS TO FUNCTIONAL GROUPS}

Plant growth-promoting rhizobacteria strains occur in various taxonomic groups, and these different taxonomic groups may be present simultaneously in a given soil (Kyselková et al., 2009; Almario et al., 2013a). This suggests that taxonomically-contrasted PGPR strains may coexist in soil and colonize a same rhizosphere, along with all non-PGPR members of the bacterial community. This possibility has been documented repeatedly, especially when characterizing the taxonomic status of bacterial isolates selected based on their positive effect on plant growth or health, their ability to inhibit phytopathogens, or the occurrence of a particular gene or property of relevance for PGPR effect (Bertrand et al., 2001; Barriuso et al., 2005; Upadhyay et al., 2009). In fact, this possibility seems to be the rule rather than the exception. PGPR populations contributing to a same type of function (i.e., ISR, nitrogen fixation, nutrient solubilization, plant development enhancement, etc.) belong to a same functional group. Functional group approaches can be implemented when specific genes are documented. For instance, nitrogen fixers can be assessed using the nifH gene, which encodes the dinitrogenase subunit of the nitrogenase. Its sequence is well conserved within the functional group and it is commonly used as marker to monitor the size and diversity of the diazotrophic community (Poly et al., 2001; Dixon and Kahn, 2004). Some of these PGPR functional groups are taxonomically narrow, such as the Pseudomonas DAPG producers (Frapolli et al., 2012). In contrast, others are much more diversified, and certain bacterial functional groups may also comprise both PGPR and non-PGPR strains. For instance, nitrogen fixers include PGPR as well as mutualistic symbionts and even a few pathogens (Herridge et al., 2008).

When considering PGPR-plant relationship in fields, the cooccurrence of genetically contrasted PGPR strains from a same functional group in the rhizosphere has two consequences. First, the activity of a given PGPR functional group corresponds to the resulting contributions of all active individual cells from each type of bacterium within the functional group. If synergistic effects occur between the PGPR populations, the expected performance level for the PGPR function might be higher than if only one type of strain was involved. On this basis, knowing the size of the functional group will help understand the potential importance of the corresponding function. Indeed, for functions leading to enhanced nutrient availability to the plant, such as nitrogen fixation or phosphorus solubilization, the higher the better. For others where optimality matters, such as the production of auxinic signals (Dobbelaere et al., 1999; Spaepen et al., 2007b), the performance level of the functional group will need fine-tuning to avoid production levels too small or too great. How this is ecologically regulated at the scale of the corresponding functional group is unknown, but it raises the possibility of co-evolutionary patterns. To bridge the gap between the potential of a plant-beneficial PGPR function and its actual implementation by PGPR strains, the regulatory effects need also to be taken into consideration. Some of these regulatory effects will be common to all members of the functional group (Prigent-Combaret et al., 2008). However, other regulatory effects may be relevant for a subset only of the functional group. For instance, zinc sulfate stimulates DAPG production in certain but not all genetic groups of Pseudomonas PGPR strains (Duffy and Défago, 1999).

Second, the relationships amongst the different PGPR strains co-occurring in a same rhizosphere are important. Interactions will take place within a functional group, as illustrated above with QS regulation of phenazine production in fluorescent Pseudomonas PGPR (Pierson et al., 1994). Interactions may also take place between different PGPR functional groups (Figure 3), integrating competitive and inhibitory effects (Couillerot et al., 2011), signal jamming (Boyer and Wisniewski-Dyé, 2009) and positive signaling (Combes-Meynet etal., 2011), as well as more indirect processes such as root exudation modifications (Phillips et al., 2004; Dardanelli et al., 2010). These interactions have the potential to modulate spatial colonization patterns of PGPR on roots (Couillerot et al., 2011) and to affect PGPR performance (Pierson et al., 1998). This also suggests that members of different PGPR functional groups can function together, as consortia, with the possibility of synergistic effects or, contrariwise, antagonistic effects. These positive effects may be sought by implementing inoculation procedures in which different types of plant-beneficial microorganisms are used in combination, as highlighted above. Even in this context, interactions between the different microbial strains that are inoculated and indigenous microorganisms (including PGPR) probably matter.

\section{IMPACT OF PLANT GENOTYPES ON PGPR FUNCTIONAL GROUPS}

Plants at species, sub-species and variety levels exhibit substantial genetic and phenotypic diversity (Salamini et al., 2002; Vaughan et al., 2008). In the rhizosphere, different plant genotypes will have a different impact on the number, diversity and activity of microorganisms (Bais et al., 2006; Micallef et al., 2009). This has been shown when comparing different plant species (Grayston et al., 1998; Costa et al., 2006; Berg and Smalla, 2009) or varieties within species (Germida and Siciliano, 2001; van Overbeek and van Elsas, 2008; İnceoğlu et al., 2010; Bouffaud et al., 2012). It entails differences noticeably in root system structure, root exudation profile, and nutrient acquisition (Czarnota et al., 2003; Comas and Eissenstat, 2009). These effects have also been evidenced when considering microbial functional groups of PGPR or where PGPR predominate.

Nitrogen-fixing bacteria are particularly important for plant nitrogen nutrition (Hsu and Buckley, 2009; Turk et al., 2011). The analysis of functional groups indicated that the size and/or composition of nitrogen-fixing bacteria is influenced by host plant features (Figure 3), both at plant species (Perin et al., 2006) and variety levels (Coelho et al., 2009; Wu et al., 2009). Analysis of nifH gene transcripts extracted from the rhizosphere showed that only a fraction of the community expresses nifH, and that the corresponding bacterial species differed according to the plant variety, pointing to an influence of plant genotype on the functioning of nitrogen-fixing bacteria (Knauth et al., 2005; 
Mårtensson etal., 2009; Orr etal., 2011). Similar findings were made with the functional group of phosphate solubilizers (Richardson and Simpson, 2011). Their selection by roots varies according to host plant species (Kaeppler et al., 2000; Chen et al., 2002; Ramaekers et al., 2010).

Other functional groups, such as those involved in plant protection from parasites, act mainly by competition or antagonism, even though direct ISR effects might also take place (Weller et al., 2012). For these microorganisms as well, plant genotype can have a major effect on microbial selection processes, as shown with fluorescent pseudomonads producing DAPG (Picard et al., 2004; Bergsma-Vlami et al., 2005; Picard and Bosco, 2006; Frapolli et al., 2010) or hydrogen cyanide (Jamali et al., 2009; Rochat et al., 2010). Plant-genotype differences in rhizosphere ecology may also matter in terms of plant protection efficiency (Smith and Goodman, 1999; Mazzola and Gu, 2002; Mazzola et al., 2004; Ryan et al. 2004).

\section{CONCLUSION}

Plants have evolved different types of biotic interactions with soil microbial populations, ranging from commensalism to mutualism. Within this continuum of interactions, the plant-PGPR cooperation plays a major role by enhancing growth and health of widely diverse plants. Recent progress has helped to understand key features regarding the modes of action and ecology of plant-PGPR interactions, but major knowledge gaps remain. In terms of molecular signaling and functioning, whether PGPR fine-tune plant hormonal pathways similar to those induced by pathogens and symbionts and/or trigger yet-unknown specific pathways requires clarification.

Plant growth-promoting rhizobacteria are able to modulate RSA and in fine the vegetative growth and physiology of the whole plant. RSA effects have long been associated with the production of IAA by PGPR. Surprisingly, bacterial modulation of plant auxin distribution and IAA signal transduction pathways, independently of IAA production by PGPR, has also been revealed. It is obviously a step forward in our understanding of plant-PGPR cooperation but it does not fully clarify the bacterial functions

\section{REFERENCES}

Ahn, S. J., Shin, R., and Schachtman, D. P. (2004). Expression of KT/KUP genes in Arabidopsis and the role of root hairs in $\mathrm{K}^{+}$uptake. Plant Physiol. 134, 1135-1145. doi: 10.1104/pp.103.034660

Aira, M., Gómez-Brandón, M., Lazcano, C., Bååth, E., and Domínguez, J. (2010). Plant genotype strongly modifies the structure and growth of maize rhizosphere microbial communities. Soil Biol. Biochem. 42, 22762281. doi: 10.1016/j.soilbio.2010. 08.029

Ait Barka, E., Nowak, J., and Clement, C. (2006). Enhancement of chilling resistance of inoculated grapevine plantlets with a plant growth-promoting rhizobacterium,

and plant hormonal networks involved. Plant hormones regulate genes for the biosynthesis of other hormones or components of hormonal pathways. Consequently, it is possible that PGPR can affect these cross-talks too. It would explain why PGPR can have such pleiotropic effects on plants. One of the major current scientific challenges lying ahead is to understand how these different signaling pathways are integrated to coordinate plant growth and development, and how PGPR influence the plant hormonal network.

Distinct PGPR populations present in a same soil can express plant-beneficial properties in concert. As aforementioned, the relationships between plants and their rhizo-microbiome are complex and vary both according to plant genotypes and soil inhabiting populations (and thus local soil properties, more generally speaking). Next-generation sequencing technologies have started to reveal their taxonomic and functional diversity. They have begun to bring new knowledge on the ecology of PGPR functional groups. In the near future, it is expected that metatranscriptomics and metaproteomics will develop drastically, and will allow further progress on the understanding of the activity and ecological behavior of natural PGPR populations within the rhizosphere. However, given the heterogeneity in space and time of the rhizosphere habitat, samplings at different times and locations within the plant rhizosphere and within fields will be essential to better understand the ecology and performance of PGPR at plant and field plot scales. Nevertheless, despite being very reductionist, mechanistic functional studies using one PGPR and one plant are still useful to investigate the ways PGPR exert beneficial effects on plants. We think that the most important advances on plantPGPR cooperation will be brought in the future by combining both ecology and functional biology approaches.

\section{ACKNOWLEDGMENTS}

We thank Région Rhône-Alpes for Jordan Vacheron's Ph.D. fellowship and acknowledge funding from the ANR projects SymbioMaize (ANR-12-JSV7-0014-01), AzoRiz (ANR-08-BLAN0098) and Azodure (ANR-12-AGRO-0008), and the FW6 STREP project MicroMaize (036314) from the European Union.

genes in biocontrol Pseudomonas protegens. Mol. Plant Microbe Interact. 26, 566-574. doi: 10.1094/MPMI-1112-0274-R

Aloni, R., Aloni, E., Langhans, M., and Ullrich, C. I. (2006). Role of cytokinin and auxin in shaping root architecture: regulating vascular differentiation, lateral root initiation, root apical dominance and root gravitropism. Ann. Bot. 97, 883-893. doi: 10.1093/aob/mcl027

Alonso, J. M., Stepanova, A. N., Leisse, T. J., Kim, C. J., Chen, H. M. Shinn, P., et al. (2003). Genome-wide insertional mutagenesis of Arabidopsis thaliana. Science 301, 653-657. doi: 10.1126/science.1086391

Anderson, A. J., and Guerra, D. (1985). Responses of bean to root colonization with Pseudomonas putida in a hydroponic system. Phytopathology 75, 992-995. doi: 10.1094/Phyto-75992

Arkhipova, T. N., Prinsen, E., Veselov, S. U., Martinenko, E. V., Melentiev, A. I., and Kudoyarova, G. R. (2007). Cytokinin producing bacteria enhance plant growth in drying soil. Plant Soil 292, 305-315. doi: 10.1007/s11104-007-9233-5

Bacilio-Jiménez, M., Aguilar-Flores, S., Ventura-Zapata, E., Perez-Campos, E., Bouquelet, S., and Zenteno, E. (2003). Chemical characterization of root exudates from rice (Oryza sativa) and their effects on the chemotactic response of endophytic bacteria. Plant Soil 249, 271-277. doi: 10.1023/A:1022888900465

Badri, D. V., Weir, T. L., van der Lelie, D., and Vivanco, J. M. 
(2009). Rhizosphere chemical dialogues: plant-microbe interactions. Curr. Opin. Biotechnol. 20, 642-650. doi: 10.1016/j.copbio.2009.09.014

Baehler, E., Bottiglieri, M., PechyTarr, M., Maurhofer, M., and Keel, C. (2005). Use of green fluorescent protein-based reporters to monitor balanced production of antifungal compounds in the biocontrol agent Pseudomonas fluorescens CHA0. J. Appl. Microbiol. 99, 24-38. doi: 10.1111/j.1365-2672.2005.02597.x

Bais, H. P., Weir, T. L., Perry, L. G., Gilroy, S., and Vivanco, J. M. (2006). The role of root exudates in rhizosphere interactions with plants and other organisms. Annu. Rev. Plant Biol. 57, 233-266. doi: 10.1146/annurev.arplant.57.032905. 105159

Bakker, P. A., Pieterse, C. M., and van Loon, L. C. (2007). Induced systemic resistance by fluorescent Pseudomonas spp. Phytopathology 97, 239-243. doi: 10.1094/PHYTO-97-20239

Barea, J. M., Pozo, M. J., Azcón, R., and Azcón-Aguilar, C. (2005). Microbial co-operation in the rhizosphere. J. Exp. Bot. 56, 1761-1778. doi: 10.1093/jxb/eri197

Barriuso, J., Pereyra, M. T., Lucas Garcia, J. A., Megias, M., Gutierrez Manero, F. J., and Ramos, B. (2005). Screening for putative PGPR to improve establishment of the symbiosis Lactarius deliciosus-Pinus sp. Microb. Ecol. 50, 82-89. doi: 10.1007/s00248-0040112-9

Bashan, Y., and de-Bashan, L. E. (2010). How the plant growthpromoting bacterium Azospirillum promotes plant growth - a critical assessment. Adv. Agron. 108, 77136. doi: 10.1016/S0065-2113(10) 08002-8

Bauer, H., Ache, P., Lautner, S., Fromm, J., Hartung, W., Al-Rasheid Khaled, A. S., et al. (2013). The stomatal response to reduced relative humidity requires guard cell-autonomous $\mathrm{ABA}$ synthesis. Curr. Biol. 1, 53-57. doi: 10.1016/j.cub.2012.11.022

Bekri, M. A., Desair, J., Keijers, V., Proost, P., Searle-van Leeuwen, M., Vanderleyden, J., et al. (1999). Azospirillum irakense produces a novel type of pectate lyase. J. Bacteriol. 181, 2440-2447.

Benhamou, N., Belanger, R. R., and Paulitz, T. C. (1996). Pre-inoculation of Ri T-DNA-transformed pearoots with Pseudomonas fluorescens inhibits colonization by Pythium ultimum Trow: an ultrastructural and cytochemical study. Planta 199, 105-117. doi: 10.1007/BF00196887
Benizri, E., Baudoin, E., and Guckert, A. (2001). Root colonization by inoculated plant growth promoting rhizobacteria. Biocontrol Sci. Technol. 11, 557-574. doi: 10.1080/09583150120076120

Berg, G., and Smalla, K. (2009). Plant species and soil type cooperatively shape the structure and function of microbial communities in the rhizosphere. FEMS Microbiol. Ecol. 68, 1-13. doi: 10.1111/j.15746941.2009.00654.x

Bergsma-Vlami, M., Prins, M. E., and Raaijmakers, J. M. (2005). Influence of plant species on population dynamics, genotypic diversity and antibiotic production in the rhizosphere by indigenous Pseudomonas spp. FEMS Microbiol. Ecol. 52, 59-69. doi: 10.1016/j.femsec.2004. 10.007

Berthomieu, P., Conejero, G., Nublat, A., Brackenbury, W. J., Lambert, C., Savio, C., et al. (2003). Functional analysis of AtHKT1 in Arabidopsis shows that $\mathrm{Na}^{+}$recirculation by the phloem is crucial for salt tolerance. $E M B O$ J. 22, 2004-2014. doi: 10.1093/emboj/cdg207

Bertin, C., Yang, X. H., and Weston, L. A. (2003). The role of root exudates and allelochemicals in the rhizosphere. Plant Soil 256, 67-83. doi: 10.1023/A:1026290508166

Bertrand, H., Nalin, R., Bally, R., and Cleyet-Marel, J. C. (2001). Isolation and identification of the most efficient plant growth-promoting bacteria associated with canola (Brassica napus). Biol. Fertil. Soils 33, 152-156. doi: 10.1007/s003740000305

Bertrand, H., Plassard, C., Pinochet, X., Touraine, B., Normand, P., and Cleyet-Marel, J. C. (2000). Stimulation of the ionic transport system in Brassica napus by a plant growthpromoting rhizobacterium (Achromobacter sp.). Can. J. Microbiol. 46, 229-236. doi: 10.1139/cjm-463-229

Bharti, N., Yadav, D., Barnawal, D., Maji, D., and Kalra, A. (2013). Exiguobacterium oxidotolerans, a halotolerant plant growth promoting rhizobacteria, improves yield and content of secondary metabolites in Bacopa monnieri (L.) Pennell under primary and secondary salt stress. World J. Microbiol. Biotechnol. 29, 379-387. doi: 10.1007/s11274-012-1192-1

Blaha, D., Prigent-Combaret, C., Mirza, M. S., and Moënne-Loccoz, Y. (2006). Phylogeny of the 1aminocyclopropane-1-carboxylic acid deaminase-encoding gene acdS in phytobeneficial and pathogenic Proteobacteria and relation with strain biogeography. FEMS Microbiol. Ecol. 56, 455-470. doi: 10.1111/j.1574-6941.2006.00082.x Bleecker, A. B., and Kende, H. (2000). Ethylene: a gaseous signal molecule in plants. Annu. Rev. Cell Dev. Biol. 16, 1-18. doi: 10.1146/annurev.cellbio.16.1.1

Boddey, R. M., Urquiaga, S., Alves, B. J. R., and Reis, V. (2003). Endophytic nitrogen fixation in sugarcane: present knowledge and future applications. Plant Soil 252, 139-149. doi: 10.1023/A:1024152126541

Bottini, R., Cassán, F., and Piccoli, P. (2004). Gibberellin production by bacteria and its involvement in plant growth promotion and yield increase. Appl. Microbiol. Biotechnol. 65 , 497-503. doi: 10.1007/s00253-0041696-1

Bouffaud, M. L., Kyselkova, M., Gouesnard, B., Grundmann, G., Muller, D., and Moënne-Loccoz, Y. (2012). Is diversification history of maize influencing selection of soil bacteria by roots? Mol. Ecol. 21, 195206. doi: 10.1111/j.1365-294X.2011. 05359.x

Boyer, M., Bally, R., Perrotto, S., Chaintreuil, C., and Wisniewski-Dyé, F. (2008). A quorum-quenching approach to identify quorumsensing-regulated functions in Azospirillum lipoferum. Res. Microbiol. 159, 699-708. doi: 10.1016/j. resmic.2008.08.003

Boyer, M., and Wisniewski-Dyé, F. (2009). Cell-cell signaling in bacteria: not simply a matter of quorum. FEMS Microbiol. Ecol. 70, 1-19. doi: 10.1111/j.1574-6941.2009.00745.x

Brandl, M. T., and Lindow, S. E. (1998). Contribution of indole-3-acetic acid production to the epiphytic fitness of Erwinia herbicola. Appl. Environ. Microbiol. 64, 3256-3263.

Brazelton, J. N., Pfeufer, E. E., Sweat, T. A., McSpadden Gardener, B. B., and Coenen, C. (2008). 2,4diacetylphloroglucinol alters plant root development. Mol. Plant Microbe. Interact. 21, 1349-1358. doi: 10.1094/MPMI-21-10-1349

Brodhagen, M., Henkels, M. D., and Loper, J. E. (2004). Positive autoregulation and signaling properties of pyoluteorin, an antibiotic produced by the biological control organism Pseudomonas fluorescens Pf-5. Appl. Environ. Microbiol. 70, 17581766. doi: 10.1128/AEM.70.3.17581766.2004

Brusamarello-Santos, L. C. C., Pacheco, F., Aljanabi, S. M. M., Monteiro, R. A., Cruz, L. M., Baura, V. A., et al. (2012). Differential gene expression of rice roots inoculated with the diazotroph Herbaspirillum seropedicae. Plant Soil 356, 113-125. doi: 10.1007/s11104-011-1044-z

Bulgarelli, D., Schlaeppi, K., Spaepen, S., Ver Loren van Themaat, E., and Schulze-Lefert, P. (2013). Structure and functions of the bacterial microbiota of plants. Annu. Rev. Plant Biol. 64, 807-838. doi: 10.1146/annurevarplant-050312-120106

Burdman, S., Volpin, H., Kigel, J., Kapulnik, Y., and Okon, Y. (1996). Promotion of nod gene inducers and nodulation in common bean (Phaseolus vulgaris) roots inoculated with Azospirillum brasilense Cd. Appl. Environ. Microbiol. 62, 3030-3033.

Cacciari, I., Lippi, D., Pietrosanti, T., and Pietrosanti, W. (1989). Phytohormone-like substances produced by single and mixed diazotrophic cultures of Azospirillum and Arthrobacter. Plant Soil 115, 151153. doi: 10.1007/BF02220706

Cartieaux, F., Thibaud, M. C., Zimmerli, L., Lessard, P., Sarrobert, C., David, P., et al. (2003). Transcriptome analysis of Arabidopsis colonized by a plantgrowth promoting rhizobacterium reveals a general effect on disease resistance. Plant J. 36, 177-188. doi: 10.1046/j.1365-313X.2003.01867.x

Casimiro, I., Marchant, A., Bhalerao, R. P., Beeckman, T., Dhooge, S., Swarup, R., etal. (2001). Auxin transport promotes Arabidopsis lateral root initiation. Plant Cell 13, 843-852.

Cassán, F., Perrig, D., Sgroy, V., Masciarelli, O., Penna, C., and Luna, V. (2009). Azospirillum brasilense Az39 and Bradyrhizobium japonicum E109, inoculated singly or in combination, promote seed germination and early seedling growth in corn (Zea mays L.) and soybean (Glycine max L.) Eur. J. Soil Biol. 45, 28-35. doi: 10.1016/j.ejsobi.2008.08.005

Chamam, A., Sanguin, H., Bellvert, F., Meiffren, G., Comte, G., Wisniewski-Dyé, F., et al. (2013). Plant secondary metabolite profiling evidences strain-dependent effect in the Azospirillum-Oryza sativa association. Phytochemistry 87, 65-77. doi: 10.1016/j.phytochem.2012.11.009

Chaparro, J. M., Badri, D. V., Bakker, M. G., Sugiyama, A., Manter, D. K., and Vivanco, J. M. (2013). Root exudation of phytochemicals in Arabidopsis follows specific patterns that are developmentally programmed and correlate with soil microbial functions. PLOS ONE 8:e55731. doi: 10.1371/journal.pone.0055731

Chen, C. R., Condron, L. M., Davis, M. R., and Sherlock, R. R. (2002). Phosphorus dynamics in the rhizosphere of perennial ryegrass (Lolium 
perenne L.) and radiata pine (Pinus radiata D. Don.). Soil Biol. Biochem. 34, 487-499. doi: 10.1016/S00380717(01)00207-3

Chin-A-Woeng, T. F., van den Broek, D., de Voer, G., van der Drift, K. M., Tuinman, S., Thomas-Oates, J. E., et al. (2001). Phenazine-1carboxamide production in the biocontrol strain Pseudomonas chlororaphis PCL1391 is regulated by multiple factors secreted into the growth medium. Mol. Plant Microbe. Interact. 14, 969-979. doi: 10.1094/MPMI.2001.14.8.969

Coelho, M. R. R., Marriel, I. E., Jenkins, S. N., Lanyon, C. V., Seldin, L., and O'Donnell, A. G. (2009). Molecular detection and quantification of nifH gene sequences in the rhizosphere of sorghum (Sorghum bicolor) sown with two levels of nitrogen fertilizer. Appl. Soil Ecol. 42, 48-53. doi: 10.1016/j.apsoil.2009.01.010

Cohen, A. C., Bottini, R., and Piccoli, P. N. (2008). Azospirillum brasilense $\mathrm{Sp} 245$ produces ABA in chemically-defined culture medium and increases ABA content in Arabidopsis plants. Plant Growth Regul. 54, 97-103. doi: 10.1007/s10725-0079232-9

Comas, L. H., and Eissenstat, D. M. (2009). Patterns in root trait variation among 25 co-existing North American forest species. New Phytol. 182, 919-928. doi: 10.1111/j.14698137.2009.02799.x

Combes-Meynet, E., Pothier, J. F., Moënne-Loccoz, Y., and Prigent-Combaret, C. (2011). The Pseudomonas secondary metabolite 2,4-diacetylphloroglucinol is a signal inducing rhizoplane expression of Azospirillum genes involved in plant-growth promotion. Mol. Plant Microbe. Interact. 24, 271-284. doi: 10.1094/MPMI-07-10-0148

Compant, S., Clément, C., and Sessitsch, A. (2010). Plant growthpromoting bacteria in the rhizoand endosphere of plants: their role, colonization, mechanisms involved and prospects for utilization. Soil Biol. Biochem. 42, 669-678. doi: 10.1016/j.soilbio.2009.11.024

Contesto, C., Desbrosses, G., Lefoulon, C., Bena, G., Borel, F., Galland, M., etal. (2008). Effects of rhizobacterial ACC deaminase activity on Arabidopsis indicate that ethylene mediates local root responses to plant growth-promoting rhizobacteria. Plant Sci. 1-2, 178-189. doi: 10.1016/j.plantsci.2008.01.020

Contesto, C., Milesi, S., Mantelin, S., Zancarini, A., Desbrosses, G., Varoquaux, F., et al.
(2010). The auxin-signaling pathway is required for the lateral root response of Arabidopsis to the rhizobacterium Phyllobacterium brassicacearum. Planta 232, 1455 1470. doi: 10.1007/s00425-0101264-0

Costa, R., Götz, M., Mrotzek, N., Lottmann, J., Berg, G., and Smalla, K. (2006). Effects of site and plant species on rhizosphere community structure as revealed by molecular analysis of microbial guilds. FEMS Microbiol. Ecol. 56, 236-249. doi: 10.1111/j.1574-6941.2005.00026.x

Couillerot, O., Combes-Meynet, E., Pothier, J. F., Bellvert, F., Challita, E., Poirier, M. A., et al. (2011). The role of the antimicrobial compound 2,4-diacetylphloroglucinol in the impact of biocontrol Pseudomonas fluorescens F113 on Azospirillum brasilense phytostimulators. Microbiology 157, 1694-1705. doi: 10.1099/mic.0.043943-0

Couillerot, O., Prigent-Combaret, C., Caballero-Mellado, J., and Moënne-Loccoz, Y. (2009). Pseudomonas fluorescens and closelyrelated fluorescent pseudomonads as biocontrol agents of soil-borne phytopathogens. Lett. Appl. Microbiol. 48, 505-512. doi: 10.1111/j.1472765X.2009.02566.x

Couillerot, O., Ramirez-Trujillo, A., Walker, V., von Felten, A., Jansa, J., Maurhofer, M., et al. (2012). Comparison of prominent Azospirillum strains in Azospirillum-PseudomonasGlomus consortia for promotion of maize growth. Appl. Microbiol. Biotechnol. 97, 4639-4649. doi: 10.1007/s00253-012-4249-z

Creus, C. M., Graziano, M., Casanovas, E. M., Pereyra, M. A., Simontacchi, M., Puntarulo, S., et al. (2005). Nitric oxide is involved in the Azospirillum brasilense-induced lateral root formation in tomato. Planta 221, 297-303. doi: 10.1007/s00425-0051523-7

Curzi, M. J., Ribaudo, C. M., Trinchero, G. D., Cura, J. A., and Pagano, E. A. (2008). Changes in the content of organic and amino acids and ethylene production of rice plants in response to the inoculation with Herbaspirillum seropedicae. J. Plant Interact. 3, 163-173. doi: 10.1080/17429140802255167

Czarnota, M. A., Rimando, A. M., and Weston, L. A. (2003). Evaluation of root exudates of seven sorghum accessions. J. Chem. Ecol. 29, 2073-2083. doi: 10.1023/A:1025634402071

Dardanelli, M. S., Manyani, H., Gonzalez-Barroso, S., RodriguezCarvajal, M. A., Gil-Serrano, A. M.,
Espuny, M. R., et al. (2010). Effect of the presence of the plant growth promoting rhizobacterium (PGPR) Chryseobacterium balustinum Aur9 and salt stress in the pattern of flavonoids exuded by soybean roots. Plant Soil 328, 483-493. doi: 10.1007/s11104-009-0127-6

de García Salamone, I. E., Hynes, R. K., and Nelson, L. M. (2001). Cytokinin production by plant growth promoting rhizobacteria and selected mutants. Can. J. Microbiol. 47, 404-411. doi: 10.1139/w01-029

De Maeyer, K., D’Aes, J., Hua, G. K., Perneel, M., Vanhaecke, L., Noppe, H., et al. (2011). N-Acylhomoserine lactone quorum-sensing signaling in antagonistic phenazine-producing Pseudomonas isolates from the red cocoyam rhizosphere. Microbiology 157, 459-472. doi: 10.1099/mic.0.04 3125-0

Desbrosses, G. J., and Stougaard, J. (2011). Root nodulation: a paradigm for how plant-microbe symbiosis influences host developmental pathways. Cell Host Microbe. 10, 348-358. doi: 10.1016/j.chom.2011.09.005

De Smet, I., Zhang, H., Inzé, D., and Beeckman, T. (2006). A novel role for abscisic acid emerges from underground. Trends Plant Sci. 11, 434-439. doi: 10.1016/j.tplants.2006.07.003

Desoignies, N., Schramme, F., Ongena, M., and Legreve, A. (2012). Systemic resistance induced by Bacillus lipopeptides in Beta vulgaris reduces infection by the rhizomania disease vector Polymyxa betae. Mol. Plant Pathol. 14, 416-421. doi: 10.1111/mpp. 12008

de Werra, P., Huser, A., Tabacchi, R., Keel, C., and Maurhofer, M. (2011). Plant- and microbe-derived compounds affect the expression of genes encoding antifungal compounds in a pseudomonad with biocontrol activity. Appl. Environ. Microbiol. 77, 2807-2812. doi: 10.1128/AEM.01760-10

Dixon, R., and Kahn, D. (2004). Genetic regulation of biological nitrogen fixation. Nat. Rev. Microbiol. 2, 621-631. doi: 10.1038/nrmicro954

Dobbelaere, S., Croonenborghs, A., Thys, A., Vande Broek, A., and Vanderleyden, J. (1999). Phytostimulatory effect of Azospirillum brasilense wild type and mutant strains altered in IAA production on wheat. Plant Soil 212, 153-162. doi: 10.1023/A:1004658000815

Dobbelaere, S., Vanderleyden, J., and Okon, Y. (2003). Plant growthpromoting effects of diazotrophs in the rhizosphere. Crit. Rev. Plant
Sci. 22, 107-149. doi: 10.1080/7136 10853

Dodd, I. C., Zinovkina, N. Y., Safronova, V. I., and Belimov, A. A. (2010). Rhizobacterial mediation of plant hormone status. Ann. Appl. Biol. 157, 361-379. doi: 10.1111/j.17447348.2010.00439.

Doornbos, R. F., van Loon, L. C., and Bakker, P. A. H. M. (2012). Impact of root exudates and plant defense signaling on bacterial communities in the rhizosphere. A review. Agron. Sustain. Dev. 32, 227-243. doi: 10.1007/s13593-011-0028-y

Drogue, B., Combes-Meynet, E., Moënne-Loccoz, Y., Wisniewski-Dyé, F., and Prigent-Combaret, C. (2013). "Control of the cooperation between plant growth-promoting rhizobacteria and crops by rhizosphere signals," in Vol. 1 and 2, Molecular Microbial Ecology of the Rhizosphere, ed. F. J. de Bruijn (NJ, USA: John Wiley \& Sons, Inc.), 281-294. doi: 10.1002/9781118297674.ch27

Drogue, B., Dore, H., Borland, S., Wisniewski-Dyé, F., and PrigentCombaret, C. (2012). Which specificity in cooperation between phytostimulating rhizobacteria and plants? Res. Microbiol. 163, 500-510. doi: 10.1016/j.resmic.2012.08.006

Dubrovsky, J. G., Esther Puente, M., and Bashan, Y. (1994). Arabidopsis thaliana as a model system for the study of the effect of inoculation by Azospirillum brasilense Sp-245 on root-hair growth. Soil Biol. Biochem. 26, 1657-1664. doi: 10.1016/00380717(94)90318-2

Duffy, B. K., and Défago, G. (1999). Environmental factors modulating antibiotic and siderophore biosynthesis by Pseudomonas fluorescens biocontrol strains. Appl. Environ. Microbiol. 65, 2429-2438.

Dutta, S., and Podile, A. R. (2010). Plant growth promoting rhizobacteria (PGPR): the bugs to debug the root zone. Crit. Rev. Microbiol. 36, 232-244. doi: $10.3109 / 10408411003766806$

El Zemrany, H., Cortet, J., Lutz, M. P., Chabert, A., Baudoin, E., Haurat, J., et al. (2006). Field survival of the phytostimulator Azospirillum lipoferum CRT1 and functional impact on maize crop, biodegradation of crop residues, and soil faunal indicators in a context of decreasing nitrogen fertilisation. Soil Biol. Biochem. 38, 1712-1726. doi: 10.1016/j.soilbio.2005.11.025

El Zemrany, H., Czarnes, S., Hallett, P. D., Alamercery, S., Bally, R., and Jocteur-Monrozier, L. (2007). Early changes in root characteristics 
of maize (Zea mays) following seed inoculation with the PGPR Azospirillum lipoferum CRT1. Plant Soil 291, 109-118. doi: 10.1007/s11104-0069178-0

Fernandez, O., Theocharis, A., Bordiec, S., Feil, R., Jacquens, L., Clement, C., et al. (2012). Burkholderia phytofirmans PsJN acclimates grapevine to cold by modulating carbohydrate metabolism. Mol. Plant Microbe. Interact. 25, 496-504. doi: 10.1094/MPMI-09-11-0245

Fester, T., Maier, W., and Strack, D. (1999). Accumulation of secondary compounds in barley and wheat roots in response to inoculation with an arbuscular mycorrhizal fungus and co-inoculation with rhizosphere bacteria. Mycorrhiza 8, 241-246. doi: 10.1007/s005720050240

Frapolli, M., Défago, G., and MoënneLoccoz, Y. (2010). Denaturing gradient gel electrophoretic analysis of dominant 2,4-diacetylphloroglucinol biosynthetic phlD alleles in fluorescent Pseudomonas from soils suppressive or conducive to black root rot of tobacco. Soil Biol. Biochem. 42, 649-656. doi: 10.1016/j.soilbio. 2010.01.005

Frapolli, M., Pothier, J. F., Défago, G., and Moënne-Loccoz, Y. (2012). Evolutionary history of synthesis pathway genes for phloroglucinol and cyanide antimicrobials in plant-associated fluorescent pseudomonads. Mol. Phylogenet. Evol. 63, 877-890. doi: 10.1016/j.ympev. 2012.02.030

Frébort, I., Kowalska, M., Hluska, T., Frébortová, J., and Galuszka, P. (2011). Evolution of cytokinin biosynthesis and degradation. J. Exp. Bot. 62, 2431-2452. doi: 10.1093/jxb/err004

Fulchieri, M., Lucangeli, C., and Bottini, R. (1993). Inoculation with Azospirillum lipoferum affects growth and gibberellin status of corn seedling roots. Plant Cell Physiol. 34, 1305-1309.

Fuqua, W. C., Winans, S. C., and Greenberg, E. P. (1994). Quorum sensing in bacteria: the LuxR-LuxI family of cell density-responsive transcriptional regulators. J. Bacteriol. 176, 269-275.

Galland, M., Gamet, L., Varoquaux, F., Touraine, B., and Desbrosses, G. (2012). The ethylene pathway contributes to root hair elongation induced by the beneficial bacteria Phyllobacterium brassicacearum STM196. Plant Sci. 190, 74-81. doi: 10.1016/j.plantsci.2012.03.008

Gans, J., Wolinsky, M., and Dunbar, J. (2005). Computational improvements reveal great bacterial diversity and high metal toxicity in soil. Science 309, 1387-1390. doi: 10.1126/science. 1112665

García-Gutiérrez, L., Zeriouh, H., Romero, D., Cubero, J., de Vicente, A., and Pérez-Gracia, A. (2013). The antagonistic strain Bacillus subtilis UMAF6639 also confers protection to melon plants against cucurbit powdery mildew by activation of jasmonate- and salicylic acid-dependent defence responses. Microb. Biotechnol. 6, 264-74. doi: 10.1111/1751-7915. 12028

Germida, J., and Siciliano, S. (2001). Taxonomic diversity of bacteria associated with the roots of modern, recent and ancient wheat cultivars. Biol. Fertil. Soil 33, 410-415. doi: 10.1007/s003740100343

Glick, B. R. (2005). Modulation of plant ethylene levels by the bacterial enzyme ACC deaminase. FEMS Microbiol. Lett. 251, 1-7. doi: 10.1016/j.femsle.2005.07.030

Glick, B. R., Cheng, Z., Czarny, J., and Duan, J. (2007). Promotion of plant growth by ACC deaminaseproducing soil bacteria. Eur. J. Plant Pathol. 119, 329-339. doi: 10.1007/s10658-007-9162-4

Gomes, N. C. M., Cleary, D. F. R., Pinto, F. N., Egas, C., Almeida, A., Cunha, A., et al. (2010). Taking root: Enduring effect of rhizosphere bacterial colonization in mangroves. PLoS ONE 5:e14065. doi: 10.1371/journal.pone.0014065

Grayston, S. J., Wang, S., Campbell, C. D., and Edwards, A. C. (1998). Selective influence of plant species on microbial diversity in the rhizosphere. Soil Biol. Biochem. 30, 369-378. doi: 10.1016/S00380717(97)00124-7

Gutiérrez-Mañero, F. J., Ramos-Solano, B., Probanza, A., Mehouachi, J., Tadeo, F. R., and Talon, M. (2001). The plant-growth promoting rhizobacteria Bacillus pumilus and Bacillus licheniformis produce high amounts of physiologically active gibberellins. Physiol. Plant. 111, 206-211. doi: 10.1034/j.13993054.2001.1110211.x

Hartmann, A., Schmid, M., Tuinen, D., and Berg, G. (2009). Plant-driven selection of microbes. Plant Soil 321, 235-257. doi: 10.1007/s11104-0089814-y

Hemashenpagam, N., and Selvaraj, T. (2011). Effect of arbuscular mycorrhizal (AM) fungus and plant growth promoting rhizomicroorganisms (PGPR's) on medicinal plant Solanum viarum seedlings. J. Environ. Biol. 32, 579-583.
Herridge, D. F., Peoples, M. B., and Boddey, R. M. (2008). Global inputs of biological nitrogen fixation in agricultural systems. Plant Soil 311, 1-18. doi: 10.1007/s11104-008-9668-3

Heulin, T., Guckert, A., and Balandreau, J. (1987). Stimulation of root exudation of rice seedlings by Azospirillum strains - carbon budget under gnotobiotic conditions. Biol. Fertil. Soil 4, 9-14.

Hontzeas, N., Zoidakis, J., Glick, B. R., and Abu-Omar, M. M. (2004). Expression and characterization of 1-aminocyclopropane1-carboxylate deaminase from the rhizobacterium Pseudomonas putida UW4: a key enzyme in bacterial plant growth promotion. Biochim. Biophys. Acta 1703, 11-19. doi: 10.1016/j.bbapap.2004.09.015

Hsu, S.-F., and Buckley, D. H. (2009). Evidence for the functional significance of diazotroph community structure in soil. ISME J. 3, 124-136. doi: 10.1038/ismej.2008.82

Hussain, A., and Hasnain, S. (2009). Cytokinin production by some bacteria: its impact on cell division in cucumber cotyledons. Afr. J. Microbiol. Res. 3, 704-712.

Iavicoli, A., Boutet, E., Buchala, A., and Metraux, J. P. (2003). Induced systemic resistance in Arabidopsis thaliana in response to root inoculation with Pseudomonas fluorescens CHA0. Mol. Plant Microbe Interact. 16, 851-858. doi: 10.1094/MPMI.2003.16.10.851

Imsande, J., and Touraine, B. (1994). N demand and the regulation of nitrate uptake. Plant Physiol. 105, 3-7.

İnceoğlu, O., Falcão Salles, J., van Overbeek, L., and van Elsas, J. D. (2010). Effects of plant genotype and growth stage on the betaproteobacterial communities associated with different potato cultivars in two fields. Appl. Environ. Microbiol. 76, 3675-3684. doi: 10.1128/AEM.00040-10

Jaeger, C. H. III, Lindow, S. E., Miller, W., Clark, E., and Firestone, M. K. (1999). Mapping of sugar and amino acid availability in soil around roots with bacterial sensors of sucrose and tryptophan. Appl. Environ. Microbiol. 65, 2685-2690.

Jaleel, C. A., Manivannan, P., Sankar, B., Kishorekumar, A., Gopi, R., Somasundaram, R., et al. (2007). Pseudomonas fluorescens enhances biomass yield and ajmalicine production in Catharanthus roseus under water deficit stress. Colloids Surf. $B$ Biointerfaces 60, 7-11. doi: 10.1016/j.colsurfb.2007.05.012

Jamali, F., Sharifi-Tehrani, A., Lutz, M., and Maurhofer, M. (2009).
Influence of host plant genotype, presence of a pathogen, and coinoculation with Pseudomonas fluorescens strains on the rhizosphere expression of hydrogen cyanide- and 2,4 diacetylphloroglucinol biosynthetic genes in $P$. fluorescens biocontrol strain CHA0. Microb. Ecol. 57, 267275. doi: 10.1007/s00248-008-9471-y Jha, Y., Subramanian, R. B., and Patel, S. (2011). Combination of endophytic and rhizospheric plant growth promoting rhizobacteria in Oryza sativa shows higher accumulation of osmoprotectant against saline stress. Acta Physiol. Plant 33 797-802. doi: 10.1007/s11738-0100604-9

Jing, Y. D., He, Z. L., and Yang, X. E. (2007). Role of soil rhizobacteria in phytoremediation of heavy metal contaminated soils. J. Zhejiang Univ. Sci. B 8, 192-207. doi: 10.1631/jzus.2007.B0192

Kaeppler, S. M., Parke, J. L., Mueller, S. M., Senior, L., Stuber, C., and Tracy, W. F. (2000). Variation among maize inbred lines and detection of quantitative trait loci for growth at low phosphorus and responsiveness to arbuscular mycorrhizal fungi. Crop Sci. 40, 358-364. doi: 10.2135/cropsci2000.402358x

Kamilova, F., Kravchenko, L. V., Shaposhnikov, A. I., Azarova, T., Makarova, N., and Lugtenberg, B. (2006). Organic acids, sugars and L-tryptophane in exudates of vegetables growing on stonewool and their effects on activities of rhizosphere bacteria. Mol. Plant Microbe Interact 9, 250-256. doi: 10.1094/MPMI-190250

Kechid, M., Desbrosses, G., Rokhsi, W., Varoquaux, F., Djekoun, A., and Touraine, B. (2013). The NRT2.5 and NRT2.6 genes are involved in growth promotion of Arabidopsis by the PGPR strain Phyllobacterium brassicacearum STM196. New Phytol. 198, 514-524. doi: 10.1111/nph. 12158

Knauth, S., Hurek, T., Brar, D., and Reinhold-Hurek, B. (2005). Influence of different Oryza cultivars on expression of nifH gene pools in roots of rice. Environ. Microbiol. 7, 1725-1733. doi: 10.1111/j.14622920.2005.00841.x

Kotur, Z., Mackenzie, N., Ramesh, S., Tyerman, S. D., Kaiser, B. N., and Glass, A. D. (2012). Nitrate transport capacity of the Arabidopsis thaliana NRT2 family members and their interactions with AtNAR2.1. New Phytol. 194, 724731. doi: 10.1111/j.1469-8137.2012. 04094.x 
Kovats, K., Binder, A., and Hohl, H. R. (1991). Cytology of induced systemic resistance of tomato to Phytophthora infestans. Planta 183, 491-496. doi: 10.1007/BF00194269

Kumar, V., Sarma, M. V., Saharan, K., Srivastava, R., Kumar, L., Sahai, V., etal. (2012). Effect of formulated root endophytic fungus Piriformospora indica and plant growth promoting rhizobacteria fluorescent pseudomonads R62 and R81 on Vigna mungo. World J. Microbiol. Biotechnol. 28, 595-603. doi: 10.1007/s11274-011-0852-x

Kyselková, M., Kopecký, J., Frapolli, M., Défago, G., Ságová-Marečková, M., Grundmann, G. L., et al. (2009). Comparison of rhizobacterial community composition in soil suppressive or conducive to tobacco black root rot disease. ISME J. 3, 1127 1138. doi: 10.1038/ismej.2009.61

Lanteri, M. L., Laxalt, A. M., and Lamattina, L. (2008). Nitric oxide triggers phosphatidic acid accumulation via phospholipase D during auxininduced adventitious root formation in cucumber. Plant Physiol. 147, 188198. doi: 10.1104/pp.107.111815

Lanteri, M. L., Pagnussat, G. C., and Lamattina, L. (2006). Calcium and calcium-dependent protein kinases are involved in nitric oxide- and auxin-induced adventitious root formation in cucumber. J. Exp. Bot. 57, 1341-1351. doi: 10.1093/jxb/erj109

Lappartient, A. G., and Touraine, B. (1996). Demand-driven control of root ATP sulfurylase activity and $\mathrm{SO}_{4}{ }^{2-}$ uptake in intact canola (the role of phloem-translocated glutathione). Plant Physiol. 111, 147157.

Lappartient, A. G., Vidmar, J. J., Leustek, T., Glass, A. D., and Touraine, B. (1999). Inter-organ signaling in plants: regulation of ATP sulfurylase and sulfate transporter genes expression in roots mediated by phloemtranslocated compound. Plant J. 18, 89-95. doi: 10.1046/j.1365313X.1999.00416.x

Lauter, F. R., Ninnemann, O., Bucher, M., Riesmeier, J. W., and Frommer, W. B. (1996). Preferential expression of an ammonium transporter and of two putative nitrate transporters in root hairs of tomato. Proc. Natl. Acad. Sci. U.S.A. 93, 8139-8144. doi: 10.1073/pnas.93.15.8139

Lavania, M., Chauhan, P. S., Chauhan, S. V., Singh, H. B., and Nautiyal, C. S. (2006). Induction of plant defense enzymes and phenolics by treatment with plant growth-promoting rhizobacteria Serratia marcescens NBRI1213.
Curr. Microbiol. 52, 363-368. doi: 10.1007/s00284-005-5578-2

Lee, K. H., and Larue, T. A. (1992). Ethylene as a possible mediator of light- and nitrate-induced inhibition of nodulation of Pisum sativum L. cv Sparkle. Plant Physiol. 100, 13341338. doi: 10.1104/pp.100.3.1334

Li, J., and Glick, B. R. (2001). Transcriptional regulation of the Enterobacter cloacae UW4 1-aminocyclopropane1-carboxylate (ACC) deaminase gene (acdS). Can. J. Microbiol. 47, 359367. doi: 10.1139/cjm-47-4-359

Lipton, D. S., Blanchar, R. W., and Blevins, D. G. (1987). Citrate, malate and succinate concentration in exudates from P-sufficient and Pstresses Medicago sativa L. seedlings. Plant Physiol. 85, 315-317. doi: 10.1104/pp.85.2.315

Liu, X., Bimerew, M., Ma, Y., Muller, H., Ovadis, M., Eberl, L., etal. (2007). Quorum-sensing signaling is required for production of the antibiotic pyrrolnitrin in a rhizospheric biocontrol strain of Serratia plymuthica. FEMS Microbiol. Lett. 270, 299-305. doi: 10.1111/j.15746968.2007.00681.x

Liu, X., Jia, J., Popat, R., Ortori, C. A., Li, J., Diggle, S. P., et al. (2011). Characterisation of two quorum sensing systems in the endophytic Serratia plymuthica strain G3: differential control of motility and biofilm formation according to life-style. BMC Microbiol. 11:26. doi: 10.1186/ 1471-2180-11-26

Lugtenberg, B. J., and Kamilova, F. (2009). Plant-growth-promoting rhizobacteria. Аnnu. Rev. Microbiol. 63, 541-556. doi: 10.1146/ annurev.micro.62.081307.162918

Lynch, J. M., and Whipps, J. M. (1990). Substrate flow in the rhizosphere. Plant Soil 129, 1-10. doi: 10.1007/BF00011685

Maketon, C., Fortuna, A. M., and Okubara, P. A. (2012). Cultivardependent transcript accumulation in wheat roots colonized by $\mathrm{Pseu}$ domonas fluorescens Q8r1-96 wild type and mutant strains. Biol. Control 60, 216-224. doi: 10.1016/j.biocontrol.2011.11.002

Malhotra, M., and Srivastava, S. (2006). Targeted engineering of Azospirillum brasilense SM with indole acetamide pathway for indoleacetic acid overexpression. Can. J. Microbiol. 52, 1078-1084. doi: 10.1139/w06-071

Malhotra, M., and Srivastava, S. (2008). An ipdC gene knock-out of Azospirillum brasilense strain SM and its implications on indole-3-acetic acid biosynthesis and plant growth promotion. Antonie Van Leeuwenhoek
93, 425-433. doi: 10.1007/s10482007-9207-x

Manero, F. J., Algar, E., Martin Gomez, M. S., Saco Sierra, M. D., and Solano, B. R. (2003). Elicitation of secondary metabolism in Hypericum perforatum by rhizosphere bacteria and derived elicitors in seedlings and shoot cultures. Pharm. Biol. 50, 1201-1209. doi: 10.3109/13880209.2012.664150

Mantelin, S., Desbrosses, G., Larcher, M., Tranbarger, T. J., Cleyet-Marel, J. C., and Touraine, B. (2006). Nitratedependent control of root architecture and $\mathrm{N}$ nutrition are altered by a plant growth-promoting Phyllobacterium sp. Planta 223, 591-603. doi: 10.1007/s00425-005-0106-y

Mantelin, S., and Touraine, B. (2004). Plant growth-promoting bacteria and nitrate availability: impacts on root development and nitrate uptake. J. Exp. Bot. 55, 27-34. doi: 10.1093/jxb/erh010

Mårtensson, L., Díez, B., Wartiainen, I., Zheng, W., El-Shehawy, R., and Rasmussen, U. (2009). Diazotrophic diversity, nifH gene expression and nitrogenase activity in a rice paddy field in Fujian, China. Plant Soil 325, 207-218. doi: 10.1007/s11104-0099970-8

Masson-Boivin, C., Giraud, E., Perret, X., and Batut, J. (2009). Establishing nitrogen-fixing symbiosis with legumes: how many rhizobium recipes? Trends Microbiol. 17, 458466. doi: 10.1016/j.tim.2009.07.004

Mazzola, M., Funnell, D. L., and Raaijmakers, J. M. (2004). Wheat cultivar-specific selection of 2,4diacetylphloroglucinol-producing fluorescent Pseudomonas species from resident soil populations. Microb. Ecol. 48, 338-348. doi: 10.1007/s00248-003-1067-y

Mazzola, M., and Gu, Y. H. (2002). Wheat genotype-specific induction of soil microbial communities suppressive to disease incited by Rhizoctonia solani anastomosis group (AG)-5 and AG-8. Phytopathology 92, 1300-1307. doi: 10.1094/PHYTO.2002.92.12.1300

Micallef, S. A., Shiaris, M. P., and Colón-Carmona, A. (2009). Influence of Arabidopsis thaliana accessions on rhizobacterial communities and natural variation in root exudates. J. Exp. Bot. 60, 1729-1742. doi: 10.1093/jxb/erp053 PMCid:PMC2671628

Miché, L., Battistoni, F., Gemmer, S., Belghazi, M., and ReinholdHurek, B. (2006). Upregulation of jasmonate-inducible defense proteins and differential colonization of roots of Oryza sativa cultivars with the endophyte Azoarcus sp. Mol. Plant Microbe Interact. 19, 502-511. doi: 10.1094/MPMI-19-0502

Miller, S. H., Browne, P., PrigentCombaret, C., Combes-Meynet, E. Morrissey, J. P., and O'Gara, F. (2009). Biochemical and genomic comparison of inorganic phosphate solubilisation in Pseudomonas species. Environ. Microbiol. Rep. 2, 403411. doi: 10.1111/j.1758-2229.2009. 00105.x

Minorsky, P. V. (2008). On the inside. Plant Physiol. 146, 323324. doi: 10.1104/pp.104.900246 PMCid:PMC2245824

Molina-Favero, C., Creus, C. M., Simontacchi, M., Puntarulo, S., and Lamattina, L. (2008). Aerobic nitric oxide production by Azospirillum brasilense Sp245 and its influence on root architecture in tomato. Mol. Plant Microbe Interact. 21, 10011009. doi: 10.1094/MPMI-21-7-1001

Moubayidin, L., Di Mambro, R., and Sabatini, S. (2009). Cytokinin-auxin crosstalk. Trends Plant Sci. 14, 557-562. doi: 10.1016/j.tplants.2009.06.010

Nazoa, P., Vidmar, J. J., Tranbarger, T. J., Mouline, K., Damiani, I., Tillard, P., etal. (2003). Regulation of the nitrate transporter gene AtNRT2.1 in Arabidopsis thaliana: responses to nitrate, amino acids and developmental stage. Plant Mol. Biol. 52, 689703. doi: $10.1023 / \mathrm{A}: 1024899808018$

Niranjan Raj, S., Lavanya, S. N., Amruthesh, K. N., Niranjana, S. R., Reddy, M. S., and Shetty, H. S. (2012). Histo-chemical changes induced by PGPR during induction of resistance in pearl millet against downy mildew disease. Biol. Control 60, 90-102. doi: 10.1016/j.biocontrol.2011.10.011

Notz, R., Maurhofer, M., Dubach, H., Haas, D., and Défago, G. (2002). Fusaric acid-producing strains of Fusarium oxysporum alter 2,4diacetylphloroglucinol biosynthetic gene expression in Pseudomonas fluorescens $\mathrm{CHA} 0$ in vitro and in the rhizosphere of wheat. Appl. Environ. Microbiol. 68, 2229-2235. doi 10.1128/AEM.68.5.2229-2235.2002

Notz, R., Maurhofer, M., SchniderKeel, U., Duffy, B., Haas, D., and Défago, G. (2001). Biotic factors affecting expression of the 2,4diacetylphloroglucinol biosynthesis gene phlA in Pseudomonas fluorescens biocontrol strain CHA0 in the rhizosphere. Phytopathology 91, 873-881. doi: 10.1094/PHYTO.2001.91.9.873

Odum, E. P., and Barrett, G. W. (2005). Fundamentals of Ecology, 5th Edn. Belmont, USA: Thomson Brooks/Cole. 
Okubara, P. A., Call, D. R., Kwak, Y. S., and Skinner, D. Z. (2010). Induction of defense gene homologues in wheat roots during interactions with Pseudomonas fluorescens. Biol. Control 55, 118-125. doi: 10.1016/j.biocontrol.2010.07.009

Ona, O., Van Impe, J., Prinsen, E., and Vanderleyden, J. (2005). Growth and indole-3-acetic acid biosynthesis of Azospirillum brasilense Sp245 is environmentally controlled. FEMS Microbiol. Lett. 246, 125-132. doi: 10.1016/j.femsle.2005.03.048

Orr, C. H., James, A., Leifert, C., Cooper, J. M., and Cummings, S. P. (2011). Diversity and activity of freeliving nitrogen-fixing bacteria and total bacteria in organic and conventionally managed soils. Appl. Environ. Microbiol. 77, 911-919. doi: 10.1128/AEM.01250-10

Overvoorde, P., Fukaki, H., and Beeckman, T. (2011). Auxin control of root development. Cold Spring Harb. Perspect. Biol. 2, a001537. doi: 10.1101/cshperspect.a001537

Parniske, M. (2008). Arbuscular mycorrhiza: the mother of plant root endosymbioses. Nat. Rev. Microbiol. 6, 763-775. doi: 10.1038/nrmicro1987

Patten, C. L., and Glick, B. R. (2002). Role of Pseudomonas putida indoleacetic acid in development of the host plant root system. Appl. Environ. Microbiol. 68, 3795-3801. doi: 10.1128/AEM.68.8.3795-3801. 2002

Penrose, D. M., Moffatt, B. A., and Glick, B. R. (2001). Determination of 1-aminocycopropane-1carboxylic acid (ACC) to assess the effects of ACC deaminase-containing bacteria on roots of canola seedlings. Can. J. Microbiol. 47, 77-80. doi: 10.1139/w00-128

Perin, L., Martínez-Aguilar, L., CastroGonzález, R., Estrada-de los Santos, P., Cabellos-Avelar, T., Guedes, H. V., etal. (2006). Diazotrophic Burkholderia species associated with field-grown maize and sugarcane. Appl. Environ. Microbiol. 72, 31033110. doi: 10.1128/AEM.72.5.31033110.2006

Perrig, D., Boiero, M. L., Masciarelli, O. A., Penna, C., Ruiz, O. A., Cassán, F. D., et al. (2007). Plant-growthpromoting compounds produced by two agronomically important strains of Azospirillum brasilense, and implications for inoculant formulation. Appl. Microbiol. Biotechnol. 75, 11431150. doi: 10.1007/s00253-0070909-9

Phillips, D. A., Fox, T. C., King, M. D., Bhuvaneswari, T. V., and Teuber, L.
R. (2004). Microbial products trigger amino acid exudation from plant roots. Plant Physiol. 136, 2887-2894. doi: 10.1104/pp.104.044222

Picard, C., and Bosco, M. (2006). Heterozygosis drives maize hybrids to select elite 2,4diacetylphloroglucinol-producing Pseudomonas strains among resident soil populations. FEMS Microbiol. Ecol. 58, 193-204. doi: 10.1111/j. 1574-6941.2006.00151.x

Picard, C., Frascaroli, E., and Bosco, M. (2004). Frequency and biodiversity of 2,4-diacetylphloroglucinol-producing rhizobacteria are differentially affected by the genotype of two maize inbred lines and their hybrid. FEMS Microbiol. Ecol. 49, 207215. doi: 10.1016/j.femsec.2004. 03.016

Piccoli, P., and Bottini, R. (1994). Effects of $\mathrm{C} / \mathrm{N}$ ratio, $\mathrm{N}$-content, $\mathrm{pH}$, and incubation time on growth and gibberellin production by Azospirillum lipoferum. Symbiosis 17, 229-236.

Pierson, E. A., Wood, D. W., Cannon, J. A., Blachere, F. M., and Pierson, L. S. III. (1998). Interpopulation signaling via $N$-acylhomoserine lactones among bacteria in the wheat rhizosphere. Mol. Plant Microbe Interact. 11, 10781084. doi: 10.1094/MPMI.1998.11. 11.1078

Pierson, L. S. III, Keppenne, V. D., and Wood, D. W. (1994). Phenazine antibiotic biosynthesis in Pseudomonas aureofaciens 30-84 is regulated by $\mathrm{PhzR}$ in response to cell density. J. Bacteriol. 176, 3966-3974.

Pieterse, C. M., Leon-Reyes, A., Van der Ent, S., and Van Wees, S. C. (2009). Networking by smallmolecule hormones in plant immunity. Nat. Chem. Biol. 5, 308-316. doi: 10.1038/nchembio. 164

Pieterse, C. M., Van Pelt, J. A., Ton, J., Parchmann, S., Mueller, M. J., Buchala, A. J., et al. (2000). Rhizobacteria-mediated induced systemic resistance (ISR) in Arabidopsis requires sensitivity to jasmonate and ethylene but is not accompanied by an increase in their production. Physiol. Mol. Plant Pathol. 57, 123-134. doi: 10.1006/pmpp.200 0.0291

Pieterse, C. M., van Wees, S. C., Hoffland, E., van Pelt, J. A., and van Loon, L. C. (1996). Systemic resistance in Arabidopsis induced by biocontrol bacteria is independent of salicylic acid accumulation and pathogenesisrelated gene expression. Plant Cell 8, 1225-1237.

Pieterse, C. M., van Wees, S. C., van Pelt, J. A., Knoester, M., Laan, R., Gerrits,
H., etal. (1998). A novel signaling pathway controlling induced systemic resistance in Arabidopsis. Plant Cell 10, 1571-1580.

Poly, F., Jocteur-Monrozier, L., and Bally, R. (2001). Improvement in the RFLP procedure for studying the diversity of nifH genes in communities of nitrogen fixers in soil. Res. Microbiol. 152, 95-103. doi: 10.1016/S0923-2508(00)01172-4

Pothier, J. F., Prigent-Combaret, C., Haurat, J., Moënne-Loccoz, Y., and Wisniewski-Dyé, F. (2008). Duplication of plasmid-borne nitrite reductase gene nirK in the wheatassociated plant growth-promoting rhizobacterium Azospirillum brasilense Sp245. Mol. Plant Microbe Interact. 21, 831-842. doi: 10.1094/MPMI-21-6-0831

Pothier, J. F., Wisniewski-Dyé, F., Weiss-Gayet, M., Moënne-Loccoz, Y., and Prigent-Combaret, C. (2007). Promoter-trap identification of wheat seed extract-induced genes in the plant-growth-promoting rhizobacterium Azospirillum brasilense Sp245. Microbiology 153, 3608-3622. doi: 10.1099/mic.0.2007/009381-0

Pozo, M. J., Van Der Ent, S., Van Loon, L. C., and Pieterse, C. M. (2008). Transcription factor MYC2 is involved in priming for enhanced defense during rhizobacteria-induced systemic resistance in Arabidopsis thaliana. New Phytol. 180, 511-523. doi: 10.1111/j.1469-8137.2008.02578.x

Prigent-Combaret, C., Blaha, D., Pothier, J. F., Vial, L., Poirier, M. A., Wisniewski-Dyé, F., et al. (2008). Physical organization and phylogenetic analysis of $a c d R$ as leucine-responsive regulator of the 1-aminocyclopropane-1-carboxylate deaminase gene acdS in phytobeneficial Azospirillum lipoferum $4 \mathrm{~B}$ and other proteobacteria. FEMS Microbiol. Ecol. 65, 202219. doi: 10.1111/j.1574-6941.2008. 00474.x

Ramaekers, L., Remans, R., Rao, I. M., Blair, M. W., and Vanderleyden, J. (2010). Strategies for improving phosphorus acquisition efficiency of crop plants. Field Crops Res. 117, 169-176. doi: 10.1016/j.fcr.2010. 03.001

Ramos-Solano, B., Algar, E., GarciaVillaraco, A., Garcia-Cristobal, J., Garcia, J. A. L., and GutierrezManero, F. J. (2010). Biotic elicitation of isoflavone metabolism with plant growth promoting rhizobacteria in early stages of development in Glycine max var. Osumi. J. Agric. Food Chem. 58, 1484-1492. doi: 10.1021/jf903299a
Raynaud, X., Jaillard, B., and Leadley, P. W. (2008). Plants may alter competition by modifying nutrient bioavailability in rhizosphere: a modeling approach. Am. Nat. 171, 44-58. doi: 10.1086/523951

Remans, R., Beebe, S., Blair, M., Manrique, G., Tovar, E., Rao, I. M., et al. (2008). Physiological and genetic analysis of root responsiveness to auxin-producing plant growth-promoting bacteria in common bean (Phaseolus vulgaris L.). Plant Soil 302, 149-161. doi: 10.1007/s11104-007-9462-7

Ribaudo, C. M., Krumpholz, E. M., Cassán, F. D., Bottini, R., Cantore, M. L., and Cura, J. A. (2006). Azospirillum sp. promotes root hair development in tomato plants through a mechanism that involves ethylene. $J$. Plant Growth Reg. 25, 175-185. doi: 10.1007/s00344-005-0128-5

Richardson, A. E., Baréa, J. M., McNeill, A. M., and Prigent-Combaret, C. (2009). Acquisition of phosphorus and nitrogen in the rhizosphere and plant growth promotion by microorganisms. Plant Soil 321, 305-339. doi: 10.1007/s11104-009-9895-2

Richardson, A. E., and Simpson, R. J. (2011). Soil microorganisms mediating phosphorus availability update on microbial phosphorus. Plant Physiol. 156, 989 996. doi: 10.1104/pp.111.175448 PMCid:PMC3135950

Riefler, M., Novak, O., Strnad, M., and Schmülling, T. (2006). Arabidopsis cytokinin receptor mutants reveal functions in shoot growth, leaf senescence, seed size, germination, root development, and cytokinin metabolism. Plant Cell 18, 40-54. doi: 10.1105/tpc.105.037796 PMCid:PMC1323483

Rochat, L., Péchy-Tarr, M., Baehler, E. Maurhofer, M., and Keel, C. (2010). Combination of fluorescent reporters for simultaneous monitoring of root colonization and antifungal gene expression by a biocontrol pseudomonad on cereals with flow cytometry. Mol. Plant Microbe Interact. 23, 949-961. doi: 10.1094/MPMI-23-70949

Roesch, L. F. W., Camargo, F. A. O., Bento, F. M., and Triplett, E. W. (2007). Biodiversity of diazotrophic bacteria within the soil, root and stem of field-grown maize. Plant Soil 302, 91-104. doi: 10.1007/s11104007-9458-3

Rothballer, M., Schmid, M., Fekete, A., and Hartmann, A. (2005). Comparative in situ analysis of ipdCgfpmut3 promoter fusions of Azospirillum brasilense strains $\mathrm{Sp} 7$ and 
Sp245. Environ. Microbiol. 7, 18391846. doi: 10.1111/j.1462-2920.2005. 00848.x

Rus, A., Yokoi, S., Sharkhuu, A., Reddy, M., Lee, B. H., Matsumoto, T. K., etal. (2001). AtHKT1 is a salt tolerance determinant that controls $\mathrm{Na}^{+}$entry into plant roots. Proc. Natl. Acad. Sci. U.S.A. 98, 1415014155. doi: 10.1073/pnas.241501798 PMCid:PMC61183

Ryan, A. D., Kinkel, L. L., and Schottel, J. L. (2004). Effect of pathogen isolate, potato cultivar, and antagonist strain on potato scab severity and biological control. Biol. Sci. Technol. 14, 301-311.

Ryu, C. M., Farag, M. A., Hu, C. H., Reddy, M. S., Wei, H. X., Pare, P. W., et al. (2003). Bacterial volatiles promote growth in Arabidopsis. Proc. Natl. Acad. Sci. U.S.A. 100, 49274932. doi: 10.1073/pnas.0730845100 PMCid:PMC153657

Saharan, B. S., and Nehra, V. (2011). Plant growth promoting rhizobacteria: a critical review. Life Sci. Med. Res. 21, 1-30.

Salamini, F., Ozkan, H., Brandolini, A., Schafer-Pregl, R., and Martin, W. (2002). Genetics and geography of wild cereal domestication in the near east. Nat. Rev. Genet. 3, 429-441.

Scheres, B., Benfey, P., and Dolan, L. (2002). Root development. Arabidopsis Book 1, e0101. doi: 10.1199/tab. 0101 PMCid:PMC3243376

Sekar, C., Prasad, N. N., and Sundaram, M. D. (2000). Enhancement of polygalacturonase activity during auxin induced para nodulation and endorhizosphere colonization of Azospirillum in rice roots. Indian J. Exp. Biol. 38, 80-83.

Selvaraj, T., Rajeshkumar, S., Nisha, M. C., Wondimu, L., and Tesso, M. (2008). Effect of Glomus mosseae and plant growth promoting rhizomicroorganisms (PGPR's) on growth, nutrients and content of secondary metabolites in Begonia malabarica Lam. Maejo Int. J. Sci. Technol. 2, 516-525.

Shaw, L. J., Morris, P., and Hooker, J. E. (2006). Perception and modification of plant flavonoid signals by rhizosphere microorganisms. Environ. Microbiol. 8, 1867-1880. doi: 10.1111/j.1462-2920.2006.01141.x

Shukla, K. P., Sharma, S., Singh, N. K., Singh, V., Tiwari, K., and Singh, S. (2011). Nature and role of root exudates: efficacy in bioremediation. Afr. J. Biotechnol. 10, 9717-9724.

Silverman, F. P., Assiamah, A. A., and Bush, D. S. (1998). Membrane transport and cytokinin action in root hairs of Medicago sativa. Planta
205, 23-31. doi: 10.1007/s0042500 50292

Smith, K. P., and Goodman, R. M. (1999). Host variation for interactions with beneficial plantassociated microbes. Annu. Rev. Phytopathol. 37, 473-491. doi: 10.1146/ annurev.phyto.37.1.473

Somers, E., Ptacek, D., Gysegom, P., Srinivasan, M., and Vanderleyden, J. (2005). Azospirillum brasilense produces the auxin-like phenylacetic acid by using the key enzyme for indole-3-acetic acid biosynthesis. Appl. Environ. Microbiol. 71, 1803 1810. doi: 10.1128/AEM.71.4.18031810.2005 PMCid:PMC1082559

Sondergaard, T. E., Schulz, A., and Palmgren, M. G. (2004). Energization of transport processes in plants. Roles of the plasma membrane $\mathrm{H}^{+}$ATPase. Plant Physiol. 136, $2475-$ 2482. doi: 10.1104/pp.104.048231 PMCid:PMC523315

Spaepen, S., Vanderleyden, J., and Remans, R. (2007a). Indole3 -acetic acid in microbial and microorganism-plant signaling. FEMS Microbiol. Rev. 31, 425448. doi: 10.1111/j.1574-6976.2007. 00072.x

Spaepen, S., Versees, W., Gocke, D., Pohl, M., Steyaert, J., and Vanderleyden, J. (2007b). Characterization of phenylpyruvate decarboxylase, involved in auxin production of Azospirillum brasilense. J. Bacteriol. 189, 7626-7633. doi: 10.1128/JB.00830-07 PMCid:PMC 2168738

Srivastava, S., Chaudhry, V., Mishra, A., Chauhan, P. S., Rehman, A., Yadav, A., etal. (2012). Gene expression profiling through microarray analysis in Arabidopsis thaliana colonized by Pseudomonas putida MTCC5279, a plant growth promoting rhizobacterium. Plant Signal. Behav. 7, 235-245. doi: 10.4161/psb.18957 PMCid:PMC3405686

Steidle, A., Sigl, K., Schuhegger, R., Ihring, A., Schmid, M., Gantner, S., et al. (2001). Visualization of $\mathrm{N}$-acylhomoserine lactone-mediated cell-cell communication between bacteria colonizing the tomato rhizosphere. Appl. Environ. Microbiol. 67, 57615770. doi: 10.1128/AEM.67.12.57615770.2001 PMCid:PMC93370

Stepanova, A. N., and Alonso, J. M. (2009). Ethylene signaling and response: where different regulatory modules meet. Curr. Opin. Plant Biol. 12, 548-555. doi: 10.1016/j.pbi.2009.07.009

Strömberg, A., and Brishammar, S. (1993). A histological evaluation of induced resistance to Phytophthora infestans (Mont.) de Bary in potato leaves. J. Phytopathol. 137, 1525. doi: 10.1111/j.1439-0434.1993.tb 01321.x

Subramoni, S., Gonzalez, J. F., Johnson, A., Pechy-Tarr, M., Rochat, L., Paulsen, I., et al. (2011). Bacterial subfamily of LuxR regulators that respond to plant compounds. Appl. Environ. Microbiol. 77, 4579 4588. doi: 10.1128/AEM.00183-11 PMCid:PMC3127701

Suzuki, S., He, Y., and Oyaizu, H. (2003). Indole-3-acetic acid production in Pseudomonas fluorescens HP72 and its association with suppression of creeping bentgrass brown patch. Curr. Microbiol. 47, 138-143. doi: 10.1007/s00284-0023968-2

Tak, H. I., Ahmad, F., and Babalola, O. O. (2013). "Advances in the application of plant growth-promoting rhizobacteria in phytoremediation of heavy metals," in Vol. 223, Reviews of Environmental Contamination and Toxicology, ed. D. M. Whitacre (New York: Springer Science Business Media), 33-52. doi: 10.1007/978-14614-5577-6_2

Teplitski, M., Robinson, J. B., and Bauer, W. D. (2000). Plants secrete substances that mimic bacterial $N$-acyl homoserine lactone signal activities and affect population density-dependent behaviors in associated bacteria. Mol. Plant Microbe Interact. 13 , 637-648. doi: 10.1094/MPMI.2000. 13.6.637

Theocharis, A., Bordiec, S., Fernandez, O., Paquis, S., Dhondt-Cordelier, S. Baillieul, F., et al. (2012). Burkholderia phytofirmans PsJN primes Vitis vinifera $\mathrm{L}$. and confers a better tolerance to low nonfreezing temperatures. Mol. Plant Microbe Interact. 25, 241-249. doi: 10.1094/MPMI-05-110124

Thuler, D. S., Floh, E. I., Handro, W., and Barbosa, H. R. (2003). Plant growth regulators and amino acids released by Azospirillum sp. in chemically defined media. Lett. Appl. Microbiol. 37, 174-178. doi: 10.1046/j.1472765X.2003.01373.x

Timmusk, S., Nicander, B., Granhall, U., and Tillberg, E. (1999). Cytokinin production by Paenibacillus polymyxa. Soil Biol. Biochem. 31, 1847-1852. doi: 10.1016/S0038-0717(99)00113-3

Touraine, B. (2004). "Nitrate uptake by roots - transporters and root development," in Nitrogen Acquisition and Assimilation in Higher Plants, eds L. J. De Kok and I. Stulen (Dordrecht:
Kluwer Academic Publishers), 1-34. doi: 10.1007/978-1-4020-2728-4_1

Turk, K. A., Rees, A. P., Zehr, J. P., Pereira, N., Swift, P., Shelley, R., et al. (2011). Nitrogen fixation and nitrogenase (nifH) expression in tropical waters of the eastern North Atlantic. ISME J. 5, 12011212. doi: 10.1038/ismej.2010.205 PMCid:PMC3146282

Ulmasov, T., Murfett, J., Hagen, G., and Guilfoyle, T. J. (1997). Aux/IAA proteins repress expression of reporter genes containing natural and highly active synthetic auxin response elements. Plant Cell 9, 1963-1971. doi: 10.1105/tpc.9. 11.1963

Upadhyay, S. K., Singh, D. P., and Saikia, R. (2009). Genetic diversity of plant growth promoting rhizobacteria isolated from rhizospheric soil of wheat under saline condition. Curr. Microbiol. 59, 489-496. doi: 10.1007/s00284-009-9464-1

van de Mortel, J. E., de Vos, R. C., Dekkers, E., Pineda, A., Guillod, L., Bouwmeester, K., et al. (2012). Metabolic and transcriptomic changes induced in Arabidopsis by the rhizobacterium Pseudomonas fluorescens SS101. Plant Physiol. 160, 2173 2188. doi: 10.1104/pp.112.207324 PMCid:PMC3510139

Vandeputte, O. M., Kiendrebeogo, M., Rajaonson, S., Diallo, B., Mol, A., El Jaziri, M., etal. (2010). Identification of catechin as one of the flavonoids from Combretum albiflorum bark extract that reduces the production of quorumsensing-controlled virulence factors in Pseudomonas aeruginosa PAO1. Appl. Environ. Microbiol. 76, 243 253. doi: 10.1128/AEM.01059-09 PMCid:PMC2798626

Van der Ent, S., Verhagen, B. W., Van Doorn, R., Bakker, D., Verlaan, M. G., Pel, M. J., et al. (2008). MYB72 is required in early signaling steps of rhizobacteriainduced systemic resistance in Arabidopsis. Plant Physiol. 146, 1293 1304. doi: 10.1104/pp.107.113829 PMCid:PMC2259080

van Overbeek, L., and van Elsas, J. D. (2008). Effects of plant genotype and growth stage on the structure of bacterial communities associated with potato (Solanum tuberosum L.). FEMS Microbiol. Ecol. 64, 283-296. doi: 10.1111/j.15746941.2008.00469.x

Vargas, L., Gurjao de Carvalho, T. L., Gomes Ferreira, P. C., Baldani, V. L., Baldani, J. I., and Hemerly, A. S. (2012). Early responses of rice 
(Oryza sativa L.) seedlings to inoculation with beneficial diazotrophic bacteria are dependent on plant and bacterial genotypes. Plant Soil 356, 127-137. doi: 10.1007/s11104-0121274-8

Vaughan, D. A., Lu, B.-R., and Tomooka, N. (2008). The evolving story of rice evolution. Plant Sci. 174, 394-408. doi: 10.1016/j.plantsci.2008.01.016

Veresoglou, S. D., and Menexes, G. (2010). Impact of inoculation with Azospirillum spp. on growth properties and seed yield of wheat: a metaanalysis of studies in the ISI Web of Science from 1981 to 2008. Plant Soil 337, 469-480. doi: 10.1007/s11104010-0543-7

Verhagen, B. W., Glazebrook, J., Zhu, T., Chang, H. S., van Loon, L. C., and Pieterse, C. M. (2004). The transcriptome of rhizobacteria-induced systemic resistance in Arabidopsis. Mol. Plant Microbe Interact. 17, 895-908. doi: 10.1094/MPMI.2004. 17.8 .895

Vessey, J. K. (2003). Plant growth promoting rhizobacteria as biofertilizers. Plant Soil 255, 571-586. doi: 10.1023/A:1026037216893

Vial, L., Cuny, C., Gluchoff-Fiasson, K., Comte, G., Oger, P. M., Faure, D., et al. (2006). N-acyl-homoserine lactone-mediated quorum-sensing in Azospirillum: an exception rather than a rule. FEMS Microbiol. Ecol. 58, 155-168. doi: 10.1111/j.15746941.2006.00153.x

von Wiren, N., Lauter, F. R., Ninnemann, O., Gillissen, B., Walch-Liu, P., Engels, C., et al. (2000). Differential regulation of three functional ammonium transporter genes by nitrogen in root hairs and by light in leaves of tomato. Plant J. 21, 167 175. doi: 10.1046/j.1365-313x.2000. 00665.x

Walker, V., Bertrand, C., Bellvert, F., Moënne-Loccoz, Y., Bally, R., and
Comte, G. (2011). Host plant secondary metabolite profiling shows a complex, strain-dependent response of maize to plant growth-promoting rhizobacteria of the genus Azospirillum. New Phytol. 189, 494 506. doi: 10.1111/j.1469-8137.2010. 03484.x

Walker, V., Couillerot, O., Von Felten, A., Bellvert, F., Jansa, J., Maurhofer, M., et al. (2012). Variation of secondary metabolite levels in maize seedling roots induced by inoculation with Azospirillum, Pseudomonas and Glomus consortium under field conditions. Plant Soil 356, 151-163. doi: 10.1007/s11104-011-0960-2

Wang, Y., Ohara, Y., Nakayashiki, H., Tosa, Y., and Mayama, S. (2005). Microarray analysis of the gene expression profile induced by the endophytic plant growth-promoting rhizobacteria, Pseudomonas fluorescens FPT9601-T5 in Arabidopsis. Mol. Plant Microbe Interact. 18, 385396. doi: 10.1094/MPMI-18-0385

Weller, D. M., Mavrodi, D. V., van Pelt, J. A., Pieterse, C. M., van Loon, L. C., and Bakker, P. A. (2012). Induced systemic resistance in Arabidopsis thaliana against Pseudomonas syringae pv. tomato by 2,4-diacetylphloroglucinol-producing Pseudomonas fluorescens. Phytopathology 102, 403-412. doi: 10.1094/PHYTO-08-11-0222

Wright, J. P., and Jones, C. G. (2006). The concept of organisms as ecosystem engineers ten years on: progress, limitations, and challenges. BioScience 56, 203-209. doi: 10.1641/0006-3568 (2006)056[0203:TCOOAE]2.0.CO;2

$\mathrm{Wu}, \mathrm{L} ., \mathrm{Ma}, \mathrm{K}$., and $\mathrm{Lu}, \mathrm{Y}$. (2009). Prevalence of betaproteobacterial sequences in nifH gene pools associated with roots of modern rice cultivars. Microb. Ecol. 57, 58-68. doi: 10.1007/s00248-008-9403-x
Yang, S. F., and Hoffman, N. E. (1984). Ethylene biosynthesis and its regulation in higher plants. Annu. Rev. Plant Physiol. 35, 155-189. doi: 10. 1146/annurev.pp.35.060184.001103

Yaxley, J. R., Ross, J. J., Sherriff, L. J., and Reid, J. B. (2001). Gibberellin biosynthesis mutations and root development in pea. Plant Physiol. 125, 627633. doi: 10.1104/pp.125.2.627 PMCid:PMC64864

Zakharova, E. A., Iosipenko, A. D., and Ignatov, V. V. (2000). Effect of watersoluble vitamins on the production of indole-3-acetic acid by Azospirillum brasilense. Microbiol. Res. 155, 209-214. doi: 10.1016/S09445013(00)80034-8

Zamioudis, C., Mastranesti, P., Dhonukshe, P., Blilou, I., and Pieterse, C. M. (2013). Unraveling root developmental programs initiated by beneficial Pseudomonas spp. bacteria. Plant Physiol. 162, 304318. doi: 10.1104/pp.112.212597 PMCid:PMC3641211

Zhang, H., Kim, M. S., Krishnamachari, V., Payton, P., Sun, Y., Grimson, M., etal. (2007). Rhizobacterial volatile emissions regulate auxin homeostasis and cell expansion in Arabidopsis. Planta 226, 839-851. doi: 10.1007/s00425-007-0530-2

Zhang, H., Kim, M. S., Sun, Y., Dowd, S. E., Shi, H., and Paré, P. W. (2008). Soil bacteria confer plant salt tolerance by tissue-specific regulation of the sodium transporter HKT1. Mol. Plant Microbe Interact. 21, 737-744. doi: 10.1094/MPMI-21-6-0737

Zhang, H., Murzello, C., Sun, Y., Kim, M. S., Xie, X., Jeter, R. M., et al. (2010). Choline and osmoticstress tolerance induced in Arabidopsis by the soil microbe Bacillus subtilis (GB03). Mol. Plant Microbe Interact. 23, 1097-1104. doi: 10.1094/MPMI23-8-1097
Zhang, H., Sun, Y., Xie, X., Kim, M. S., Dowd, S. E., and Pare, P. W. (2009). A soil bacterium regulates plant acquisition of iron via deficiency-inducible mechanisms. Plant J. 58, 568-577. doi: 10.1111/j.1365-313X.2009.03803.x

Zhuang, X. L., Chen, J., Shim, H., and Bai, Z. (2007). New advances in plant growth-promoting rhizobacteria for bioremediation. Environ. Int. 33, 406-413. doi: 10.1016/j.envint.2006.12.005

Conflict of Interest Statement: The authors declare that the research was conducted in the absence of any commercial or financial relationships that could be construed as a potential conflict of interest.

Received: 29 May 2013; accepted: 23 August 2013; published online: 17 September 2013.

Citation: Vacheron J, Desbrosses G, Bouffaud M-L, Touraine B, Moënne-Loccoz $Y$, Muller D, Legendre L, Wisniewski-Dyé $F$ and Prigent-Combaret C (2013) Plant growth-promoting rhizobacteria and root system functioning. Front. Plant Sci. 4:356. doi: 10.3389/fpls.2013.00356 This article was submitted to Functional Plant Ecology, a section of the journal Frontiers in Plant Science.

Copyright (c) 2013 Vacheron, Desbrosses, Bouffaud, Touraine, Moënne-Loccoz, Muller, Legendre, Wisniewski-Dyé and Prigent-Combaret. This is an open-access article distributed under the terms of the Creative Commons Attribution License (CC BY). The use, distribution or reproduction in other forums is permitted, provided the original author (s) or licensor are credited and that the original publication in this journal is cited, in accordance with accepted academic practice. No use, distribution or reproduction is permitted which does not comply with these terms. 